\title{
Drones for Conservation in Protected Areas: Present and Future
}

\author{
Jesús Jiménez López ${ }^{1, *}$ and Margarita Mulero-Pázmány ${ }^{2, *}$ \\ 1 MARE-Marine and Environmental Sciences Centre, Quinta do Lorde Marina, Sítio da Piedade, 9200-044 \\ Caniçal, Madeira Island, Portugal \\ 2 School of Natural Sciences and Psychology, Liverpool John Moores University, Liverpool L3 3AF, UK \\ * Correspondence: lopezjimenezjesus@mare-centre.pt (J.J.L.); M.C.MuleroPazmany@ljmu.ac.uk (M.M.-P.)
}

Received: 30 October 2018; Accepted: 7 January 2019; Published: 9 January 2019

\begin{abstract}
Park managers call for cost-effective and innovative solutions to handle a wide variety of environmental problems that threaten biodiversity in protected areas. Recently, drones have been called upon to revolutionize conservation and hold great potential to evolve and raise better-informed decisions to assist management. Despite great expectations, the benefits that drones could bring to foster effectiveness remain fundamentally unexplored. To address this gap, we performed a literature review about the use of drones in conservation. We selected a total of 256 studies, of which 99 were carried out in protected areas. We classified the studies in five distinct areas of applications: "wildlife monitoring and management"; "ecosystem monitoring"; "law enforcement"; "ecotourism"; and "environmental management and disaster response". We also identified specific gaps and challenges that would allow for the expansion of critical research or monitoring. Our results support the evidence that drones hold merits to serve conservation actions and reinforce effective management, but multidisciplinary research must resolve the operational and analytical shortcomings that undermine the prospects for drones integration in protected areas.
\end{abstract}

Keywords: protected areas; drones; RPAS; conservation; effective management; biodiversity threats

\section{Introduction}

Protected areas aim to safeguard biodiversity, preserve ecosystem services and ensure the persistence of natural heritage [1]. Despite their essential role in conservation, the allocation of resources to cope with an increasing variety of regular activities and unforeseen circumstances remains generally insufficient [2], severely affecting overall effectiveness [3]. Besides, protected areas subjected to international and national agreements must resolve their acquired responsibilities to maintain their legal status [4]. Hence, there is a demand for cost-effective, versatile and practical initiatives to attend a disparity of requirements to guarantee conservation, including a wide range of natural solutions [5], technological advances, and methods or innovative application of existing technologies [6].

In the last decade, drones (also known as unmanned aerial systems, remotely piloted aircraft systems, RPAS, UAS, UAV) have been the subject of a growing interest in both the civilian and scientific sphere, and indeed avowed as a new distinct era of remote sensing [7] for the study of the environment [8]. Drones offer a relatively risk-free and low-cost manner to rapidly and systematically observe natural phenomena at high spatio-temporal resolution [9]. For these reasons, drones have recently become a major trend in wildlife research [10,11] and management [12-14].

The success of drones can be partially explained by their great flexibility to carry different sensors and devices. The scope of application determines the best combination of aerial platform and payload. Although drones come in many different shapes and sizes, widespread small fixed-wing and rotary-wing aircrafts are frequently used for video and still photography. These consumer grade 
drones coupled with lightweight cameras and multispectral sensors can deliver professional mapping solutions at a fraction of a cost than previous photogrammetric techniques. Medium size drones can be equipped with compact thermal vision cameras, hyperspectral sensors and laser scanning such as LiDAR, with great prospects for wildlife ecology, vegetation studies and forestry applications respectively [15-17]. Even though visible and multispectral band cameras encompass the most obvious sensing devices, drones can indeed incorporate a diversity of instruments to measure many distinct physical quantities such as temperature, humidity or air pollution [18]. Additionally, large aerial platforms can lift heavier payloads and represent an appropriate solution for integrating complex systems with the capacity to remotely assist sampling, hold cargo or deliver assistance. A brief summary of platforms and sensors is given in Tables 1 and 2 (but see [19-22] for an in-depth revision).

Table 1. Classification of drones according to characteristics and applications.

\begin{tabular}{|c|c|c|c|c|c|c|c|c|c|c|c|c|c|}
\hline \multicolumn{14}{|c|}{ SIZE } \\
\hline \multicolumn{2}{|c|}{$\begin{array}{c}\text { Nano } \\
<30 \mathrm{~mm}\end{array}$} & \multicolumn{3}{|c|}{$\begin{array}{c}\text { Micro } \\
30-100 \mathrm{~mm}\end{array}$} & \multicolumn{3}{|c|}{$\begin{array}{c}\text { Mini } \\
\text { 100-300 mm }\end{array}$} & \multicolumn{2}{|c|}{$\begin{array}{c}\text { Small } \\
300-500 \mathrm{~mm}\end{array}$} & \multicolumn{3}{|c|}{$\begin{array}{c}\text { Medium } \\
500 \mathrm{~mm}-2 \mathrm{~m}\end{array}$} & $\begin{array}{l}\text { Large } \\
>2 \mathrm{~m}\end{array}$ \\
\hline \multicolumn{14}{|c|}{ Maximum Take-Off Weight (MTOW) } \\
\hline \multicolumn{3}{|c|}{$<0.5 \mathrm{Kg}$} & \multicolumn{3}{|c|}{$0.5-5 \mathrm{Kg}$} & \multicolumn{4}{|c|}{$5-25 \mathrm{Kg}$} & \multicolumn{4}{|c|}{$>25 \mathrm{Kg}$} \\
\hline \multicolumn{14}{|c|}{ RANGE (Distance/Type of Operation) } \\
\hline \multicolumn{5}{|c|}{ Close-range $<0.5$ miles } & \multicolumn{5}{|c|}{ Mid-range $0.5-5$ miles } & \multicolumn{4}{|c|}{ Long-range $5>$ miles } \\
\hline \multicolumn{5}{|c|}{ Visual Line Of Sight (VLOS) } & \multicolumn{5}{|c|}{ Extended Visual Line Of Sight (EVLOS) } & \multicolumn{4}{|c|}{ Beyond Visual Line Of Sight (BVLOS) } \\
\hline \multicolumn{14}{|c|}{ WING } \\
\hline \multicolumn{9}{|c|}{ Rotary wing } & \multicolumn{4}{|c|}{ Fixed wing } & \multirow{3}{*}{$\begin{array}{l}\text { Hybrid } \\
\text { (VTOL) }\end{array}$} \\
\hline Single & \multicolumn{8}{|c|}{ Multi-Rotor } & \multirow{2}{*}{$\begin{array}{l}\text { Low } \\
\text { Wing }\end{array}$} & \multirow{2}{*}{$\begin{array}{c}\text { Mid } \\
\text { Wing }\end{array}$} & \multirow{2}{*}{$\begin{array}{l}\text { High } \\
\text { Wing }\end{array}$} & \multirow{2}{*}{$\begin{array}{l}\text { Delta } \\
\text { Wing }\end{array}$} & \\
\hline $\begin{array}{l}\text { Dual } \\
\text { rotors }\end{array}$ & \multicolumn{2}{|c|}{ Tricopter } & Quadce & pter & \multicolumn{2}{|c|}{ Hexacopter } & \multicolumn{2}{|c|}{ Octocopter } & & & & & \\
\hline \multicolumn{14}{|c|}{ POWER } \\
\hline \multicolumn{4}{|c|}{ Electric } & \multicolumn{5}{|c|}{ Gas } & & Nitro & & & Solar \\
\hline & & & & & & & SSE & BLING & & & & & \\
\hline & $\operatorname{Rec}$ & dy-To- & Fly (RTF) & & & & ind- & Fly (BNF) & & & Imost-R & ady-to-1 & ly (ARF) \\
\hline & & & & & & & PLI & ITIONS & & & & & \\
\hline Logis & & Engi & $\begin{array}{l}\text { ivil } \\
\text { neering }\end{array}$ & & $\begin{array}{l}\text { saster } \\
\text { elief }\end{array}$ & Heri & age & $\begin{array}{c}\text { Search } \\
\text { and } \\
\text { Rescue }\end{array}$ & & $\begin{array}{l}\text { ecision } \\
\text { iculture }\end{array}$ & $\begin{array}{r}\mathrm{Na} \\
\mathrm{Resc}\end{array}$ & $\begin{array}{l}\text { ural } \\
\text { urces }\end{array}$ & $\begin{array}{c}\text { Law } \\
\text { Enforcement }\end{array}$ \\
\hline $\begin{array}{r}\text { Wild } \\
\text { Manage }\end{array}$ & e & $\begin{array}{r}\text { W } \\
\text { Fore }\end{array}$ & $\begin{array}{l}\text { ather } \\
\text { casting }\end{array}$ & & $\begin{array}{l}\text { ustrial } \\
\text { pection }\end{array}$ & Leis & & Military & & $\begin{array}{l}\text { saster } \\
\text { elief }\end{array}$ & $\begin{array}{r}\text { A } \\
\text { Photo } \\
\text { and }\end{array}$ & $\begin{array}{l}\text { rial } \\
\text { Fraphy } \\
\text { Film }\end{array}$ & Archeology \\
\hline
\end{tabular}

Note: SIZE, MTOW and RANGE: based on average values (no specific standard/regulation). ASSEMBLING: level of work required to use the drone since acquisition.

Considering the ample range of possibilities, it is not surprising that some protected areas are adopting drones for various applications. For example, to assist search and rescue [23]; protect endangered turtles from feral species [24]; monitoring invasive plant species [25]; document illegal logging and mining [26]; wetland management [27]; anti-poaching [28]; and marine litter detection [29]. Recently, a team of scientists discovered a biodiversity hotspot using drones [30], which could be argued as a convenient procedure to adequately expand protected areas as established by the Aichi Target 11 [3]. In addition, we are witnessing a continuous development of sophisticated drones and ingenious methods that target particular conservation actions, such as wildfires firefighting [31]; whale health monitoring [32]; disease vectors control [33]; or seed planting for habitat restoration [34]. The fast pace of technological advances and novel applications probably exceeded previous expectations, but also gives rise to singular circumstances that must be placed in the context of management. 
Table 2. Summary classification of sensors and devices that can be coupled to drones.

\begin{tabular}{|c|c|c|c|c|c|c|}
\hline \multicolumn{2}{|r|}{ Instrument. } & $\begin{array}{l}\text { Type of } \\
\text { Sensor }\end{array}$ & $\begin{array}{c}\text { Spatial } \\
\text { Resolution }\end{array}$ & $\begin{array}{l}\text { Spectral } \\
\text { Resolution }\end{array}$ & Weight & Costs \\
\hline \multirow{5}{*}{$\begin{array}{l}\text { Imaging } \\
\text { sensors }\end{array}$} & Visible RGB & Passive & $\begin{array}{l}\text { Very high } \\
1-5 \mathrm{~cm} / \text { pixel }\end{array}$ & $\begin{array}{c}\text { Low } \\
\text { ( } 3 \text { bands) }\end{array}$ & $\begin{array}{c}\text { Low } \\
<0.5 \mathrm{~kg}\end{array}$ & $\begin{array}{c}\text { Low } \\
\$ 100-1000\end{array}$ \\
\hline & $\begin{array}{c}\text { Near Infrared } \\
\text { (NIR) }\end{array}$ & Passive & $\begin{array}{l}\text { Very high } \\
1-5 \mathrm{~cm} / \text { pixel }\end{array}$ & $\begin{array}{c}\text { Low } \\
\text { ( } 3 \text { bands) }\end{array}$ & $\begin{array}{l}\text { Low } \\
<0.5 \mathrm{~kg}\end{array}$ & $\begin{array}{c}\text { Low } \\
\$ 100-1000\end{array}$ \\
\hline & Multispectral & Passive & $\begin{array}{c}\text { High } \\
5-10 \mathrm{~cm} / \text { pixel }\end{array}$ & $\begin{array}{c}\text { Medium } \\
\text { (5-12 bands) }\end{array}$ & $\begin{array}{l}\text { Medium } \\
0.5-1 \mathrm{~kg}\end{array}$ & $\begin{array}{c}\text { Medium } \\
\$ 1000-10,000\end{array}$ \\
\hline & Hyperspectral & Passive & $\begin{array}{c}\text { High } \\
5-10 \mathrm{~cm}\end{array}$ & $\begin{array}{c}\text { High } \\
(>50-100 \text { bands) }\end{array}$ & $\begin{array}{l}\text { Medium } \\
0.5-1 \mathrm{~kg} \\
\end{array}$ & $\begin{array}{c}\text { High } \\
\$ 10,000-50,000\end{array}$ \\
\hline & Thermal & Passive & $\begin{array}{c}\text { Medium } \\
10-50 \mathrm{~cm} / \text { pixel }\end{array}$ & $\begin{array}{c}\text { Low } \\
1 \text { band }\end{array}$ & $\begin{array}{l}\text { Medium } \\
0.5-1 \mathrm{~kg}\end{array}$ & $\begin{array}{c}\text { Medium } \\
\$ 1000-10,000\end{array}$ \\
\hline \multirow{2}{*}{$\begin{array}{l}\text { Ranging } \\
\text { sensors }\end{array}$} & $\begin{array}{c}\text { Laser scanners } \\
\text { (LiDAR) }\end{array}$ & Active & $\begin{array}{c}\text { Very high } \\
1-5 \mathrm{~cm} / \text { pixel }\end{array}$ & $\begin{array}{c}\text { Low } \\
1-2 \text { bands }\end{array}$ & $\begin{array}{c}\text { High } \\
0.5-5 \mathrm{~kg}\end{array}$ & $\begin{array}{c}\text { High } \\
\$ 10,000-50,000\end{array}$ \\
\hline & $\begin{array}{c}\text { Synthetic Aperture } \\
\text { Radars (SAR) }\end{array}$ & Active & $\begin{array}{c}\text { Medium } \\
10-50 \mathrm{~cm} / \text { pixel }\end{array}$ & $\begin{array}{c}\text { Low } \\
1 \text { band }\end{array}$ & $\begin{array}{l}\text { High } \\
>5 \mathrm{~kg}\end{array}$ & $\begin{array}{l}\text { Very high } \\
>\$ 50,000\end{array}$ \\
\hline \multicolumn{7}{|c|}{ Other sensors and devices } \\
\hline & Atmospheric sensors & \multicolumn{5}{|c|}{ Temperature, Pressure, Wind, Humidity } \\
\hline & Chemical Sensors & \multicolumn{5}{|c|}{ Gas, Geochemical } \\
\hline & Position systems & \multicolumn{5}{|c|}{ Ultrasound, Infrared, Radio Frequency, GPS } \\
\hline & Other devices & \multicolumn{5}{|c|}{ Recorder device/microphones } \\
\hline & Sampling Devices & \multicolumn{5}{|c|}{ Water, Aerobiological, Microbiological Sampling } \\
\hline & Other devices & \multicolumn{5}{|c|}{ Cargo, Spraying, Seed spreader } \\
\hline
\end{tabular}

Some authors have identified negative aspects of drones use in conservation. Potential wildlife disturbance effects [35] need to be further investigated. The use of drones as tools of coercion could weaken the environmental commitment of communities in protected areas [36], and therefore may prove counterproductive for conservation. On the other hand, the massive amount of data acquired with drones require modern, robust and computationally intensive methods to derive accurate and meaningful information [37], which may represent a technological barrier to the effective use of this technology in protected areas.

Likewise, the connection of drone advances with the most important features guiding effective management has not yet been specifically weighted and would be necessary to better align research efforts to conservation priorities. In addition, whether decision makers can take practical advantage of present and oncoming advances in the discipline remains questionable for several reasons. To find early answers to these remarks, we conducted an extensive literature review of drone applications with potential to enhance the effective management of protected areas. This perspective may help identify plausible scenarios where drones can be used in a rational and efficient manner.

\section{Methods}

We conducted a comprehensive literature search on drones in conservation up to October 2nd 2018 , in line with related studies $[10,11,35]$. All searches were done by the same person in English, mainly using Google Scholar. This was further complemented through reference harvesting, citation tracking, abstracts in conference programs, and author search, using Research Gate and Mendeley (see PRISMA Flowchart in Supplementary Figure S1 Checklist and list of studies reviewed in Table S1). We then removed duplicate and unrelated results. Finally, peer-reviewed publications were collated and revised.

Keywords on the search included drones in their various meanings and acronyms: "unmanned aircraft systems", "UAS", "remotely piloted aerial system", "RPAS", "drone", "model aircraft", 
"unmanned aerial vehicle", "UAV", "unmanned aircraft system". These were combined with terms referring to threats and common conservation measurements in protected areas: "protected area", "conservation", "ecology", "ecosystem", “habitat", "vegetation", "forest", "wetland", "reforestation", "monitoring", "survey", "sampling", "inventory", "wildlife", "fauna", “bird", "mammal", "fish", "amphibian", "reptile", "wildfire", "landslide", "remote sensing", "tourism", "ecotourism", "law enforcement", "poaching", "anti-poaching", "logging", "risk management", "pollution", and "search and rescue". In total, we applied 47 search terms and combinations using logical disjunctions.

We classified the studies into categories that represent the common threats and essential management measures in protected areas [5,38-40]. The categories are: "wildlife research and management" for those projects aimed at observing wildlife, estimating population parameters such as abundance and distribution, and establishing management measures to mitigate human-wildlife conflicts $(\mathrm{n}=96)$; "ecosystem monitoring" for applications related with the study and mapping of natural habitats $(\mathrm{n}=106)$; “Law enforcement" encompassing poaching and other illicit activities $(\mathrm{n}=6)$; "Ecotourism" referring to recreational activities and visitors management $(\mathrm{n}=3)$; “Environmental management and emergency response" spanning environmental monitoring and protection, natural hazards, search and rescue operations and similar cases $(n=45)$. We briefly tackled legal and ethical issues, including potential impact on wildlife and habitats, but also economic and technological factors, since all shape the feasibility of drones to approach conservation and environmental issues.

\section{Results and Discussion}

The literature search on drones in conservation provided a total of 256 studies. Of these, 99 describe applications that were accomplished in terrestrial and marine protected areas, according to the Protected Planet database [41]. The typology of protected areas includes national, international designations and registered private initiatives, with all UICN management categories (Ia, Ib, II, III, IV, V, VI) represented [1]. We found examples on all continents and in most ecosystems. The United States of America lead the ranking of countries where more drone studies have taken place (45), followed by Canada (26), Australia (17), China (11), Germany (11) and Spain (9). Figure 1 summarizes the selected research.

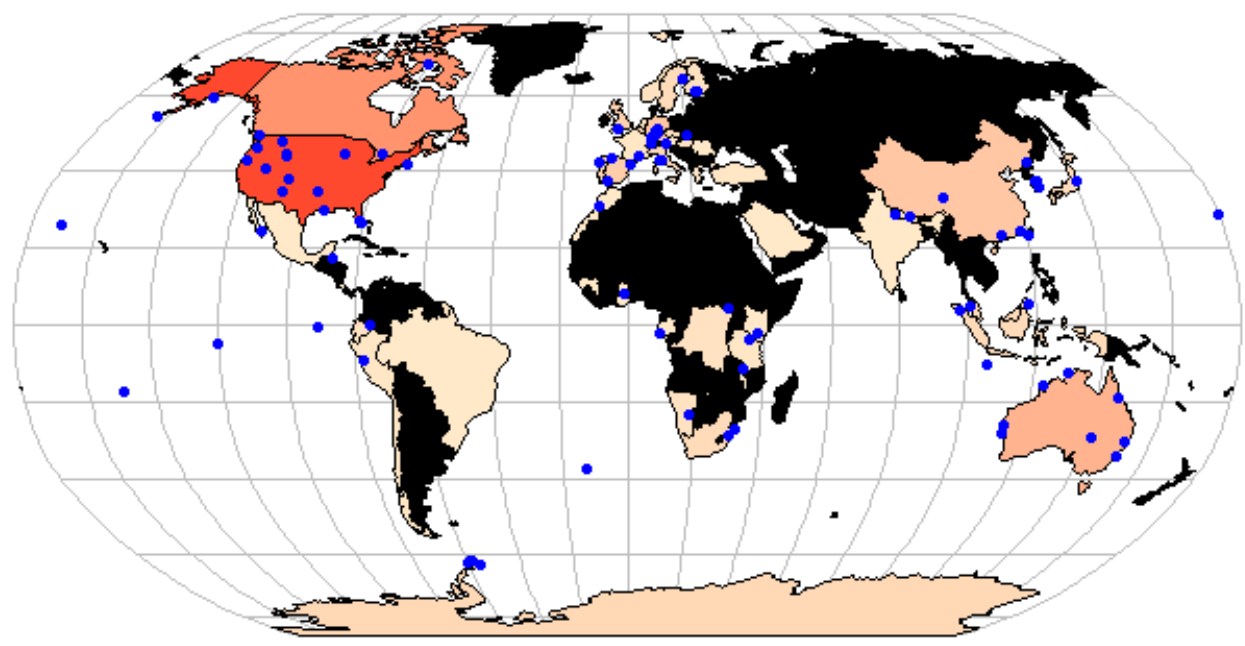

Number of articles by country $\square$ 1-10 $\square$ 10-20 $\square$ 20-40 $\square>40$

Figure 1. Cont. 


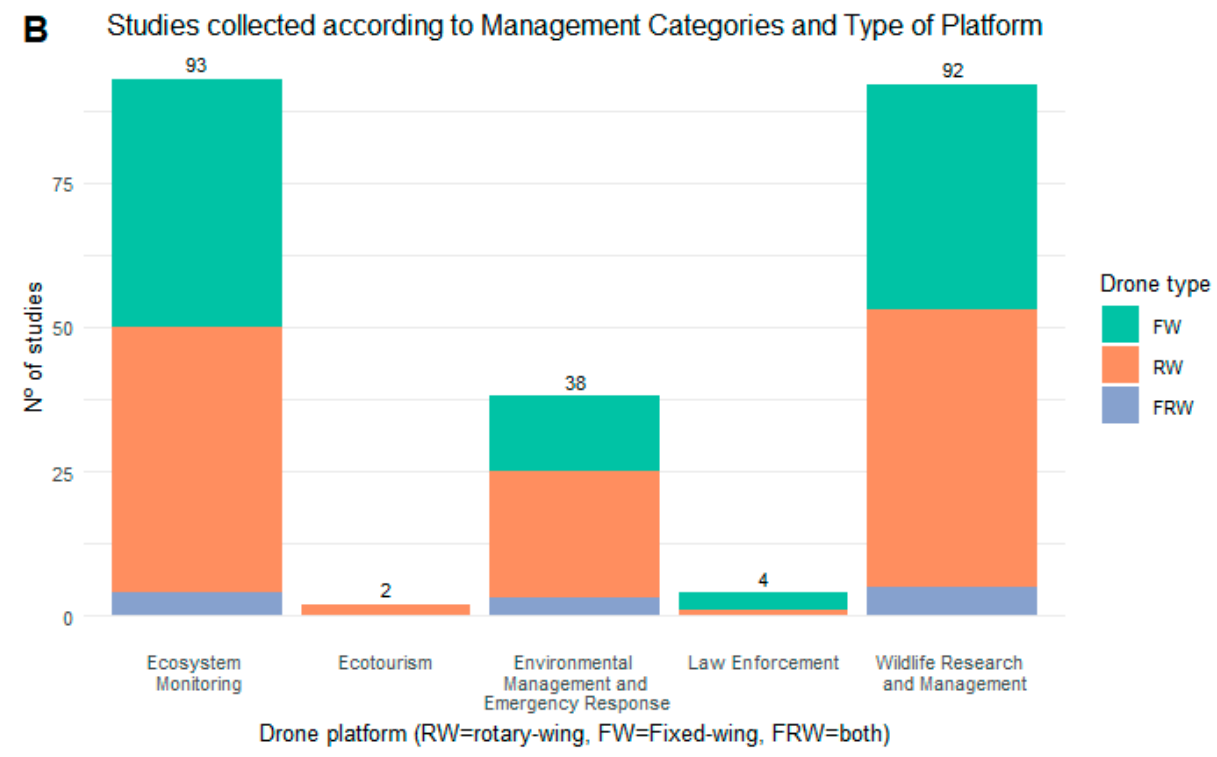

C

Drone Studies in Protected Areas by Ecoregions

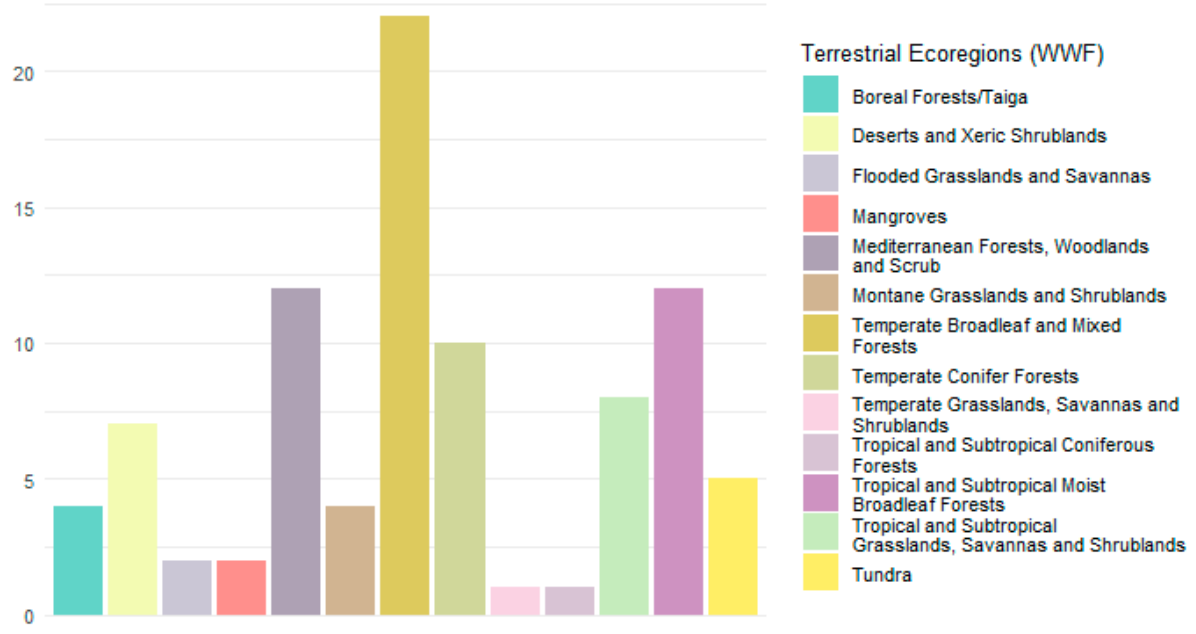

Figure 1. (A) Blue points represent studies in protected areas. Choropleth map shows location of studies by country. No studies were collected in countries colored black. (B) Only studies where type of platform was identified are shown. (C) Information extracted from WWF Terrestrial Ecoregions Map [42]. No drone studies were found in Protected Areas with Tropical and subtropical dry broadleaf forests.

The classification of the studies in categories that align with recurring aspects of conservation and management in protected areas [43] provides a framework that may help park-managers to identify feasible drone scenarios. The factors influencing effectiveness can be conveniently ascribed to the proposed categories and associated with consensual conservation actions [44]. In the next sections, we discuss the current state of the art and the challenges for the future integration of drones in protected areas.

\subsection{State of the Art: Drones in Protected Areas}

\subsubsection{Wildlife Research and Management}

Manned aircrafts have been traditionally used to complement ground-based wildlife surveys, but under-resourcing of many protected areas prevent their more widespread use. Besides, a significant number of aerial accidents with fatalities have been historically reported [45]. Moreover, 
aerial incursions are subject to visibility bias since a greater number of observers is required to guarantee an exhaustive count of populations and minimize errors [46]. Drones have emerged as a feasible alternative to surpass such inconveniences at small scales and complement modern wildlife conservation. Remotely sensed capabilities of drones offer a less invasive, non-hazardous, repetitive and reliable monitoring technique [47] to collect species abundance and distribution, document wildlife behavior, life-history and health status. Recent examples target terrestrial mammals [48-50]; marine mammals [51-55]; birds [11,56-60]; reptiles [15,61-64]; and fish [65,66]. Most surveys opted for both optical and thermal cameras, the latter especially appropriate to sense elusive species overnight, when the temperature differences between the animal body and the environment are greater [67]. Other studies implemented acoustic sensors to record songbirds [68] or combine drones with tracking systems aboard $[9,69,70]$ to collect wildlife movement and environmental data. Researchers have also devised ways to use drones for insect monitoring [71], habitat modeling [72] and sampling [73].

Protected areas often face human-wildlife conflicts in populated areas bordering their limits [74]. Some studies described the use of drones in various management tasks, such as moving elephants out of human settlements [75], mapping wildlife damage on crops to calculate compensation costs [76] or dropping fake baits targeting feral species [77]. Drones constitute an attainable low-cost alternative to assess and reduce the risk that hazardous infrastructures $[78,79]$ or mechanical harvesting $[80,81]$ pose to wildlife. Lastly, fine-scale mapping of species distribution, land-use changes and water bodies using high resolution aerial imagery hold potential to complement epidemiological and zoonotic studies [82-85], and may serve as a rapid mechanism to inform prevention and reinforce biosecurity programs.

\subsubsection{Ecosystem Monitoring}

Protected areas are reference sites for ecological monitoring. These activities provide essential information to track ecosystem changes as a result of management and environmental factors [86]. Established methods for habitat monitoring range from in situ and airborne observations to satellite-based remote sensing. The latest generation of commercial satellite sensors [87] collect images at sub-meter resolution and entail remarkable technological advances to Earth observation, but the geographical availability of products is limited and not always rapidly available. Drones are particularly appropriated to timely survey small areas at unprecedented detail [88], could be adapted to carry sampling devices and take in-situ measurements [89], and may prove advantageous to monitor Essential Biodiversity Variables (EBVs) [90]. Similarly, mapping and quantifying ecosystem services with drones constitute an efficient means to inform site design and zoning, especially when the information available is scarce, outdated and based on coarse-resolution remote sensing images. Also, monitoring habitat degradation with drones in protected areas and borderlands [91,92] represents a novel method to assess the performance of conservation actions. Finally, fine-scale habitat assessment using high resolution maps could assist, selecting suitable reintroduction sites for endangered or locally extinct species [93].

Experimental drone monitoring projects have increased noticeably, both by governmental institutions [94] and research groups, for informing on the distribution [95], health [16,96], productivity [97], composition [98], structure [99,100] and biomass [101-104] of forests using both passive and active sensors [105]. As a consequence, drone applications for inventory, characterization and habitat restoration are maturing fast, but scaling-up and linking the collected information with that coming from satellite remote sensing remains a knowledge gap [106]. However, some studies represent a step in this direction, including the following: derive and enhance ground-based forest metrics to assist modeling of ecological process at regional scale [107], validate vegetation maps from drone image interpretation $[108,109]$ or address the radiometric calibration of small multispectral cameras to allow comparisons with satellite data $[110,111]$. Drones have been used for community-based forest monitoring [112], and therefore suggested as an important asset to impulse the participation of developing countries in the carbon market (Reducing Emissions from 
Deforestation and Forest Degradation, REDD) [113]. In addition, drones have operated successfully in different ecosystems to measure the spread of invasive species [114-118]; map coastal and marine habitats [119-125]; wetlands [126-130]; grasslands [17,131,132]; savannas [133,134]; glaciers [135-137]; polar areas [138,139]; and riparian ecosystems [140-143].

\subsubsection{Law Enforcement}

Efficient control and surveillance of illegal activities lead the ranking of measures for effective management of terrestrial [144] and marine [145] protected areas. These conservation actions aim to maintain the integrity of threatened species and ecosystems in the face of human pressures, but in practice suffer from serious deficiencies [146]. Enforcement is especially challenging in large protected areas where iconic species are on the verge of extinction due to illegal hunting, fishing, encroachment or habitat loss. Drones constitute a technological advance to complement insufficient staff and resourcing in anti-poaching [12,147-149] and other less contentious acts such as vandalism or bonfires in unauthorized areas [150,151]. Drone surveillance aim to autonomously detect and track subjects integrating live streaming visible and thermal camera systems with real time vision processing techniques. However, these applications are subjected to technological and legal constraints. Real-time recognition of suspicious activity or flying in adverse weather conditions remain a work in progress [152]. The relatively low maximum flight time of modest drones is a major obstacle to cover large areas [12], but progress is noticeable. Although the last generation of long-endurance fixed-wing and hybrid aerial platforms have higher autonomy, meeting the optimal specifications requires a considerable investment [153] with uncertain benefits, especially in developing countries [154]. Besides, the main barriers to protected areas surveillance using drones take place in the legislative and socio-political sphere. The flight rules often limit flying drones beyond the visual line of sight (BVLOS), above a certain altitude or at night, precluding the surveillance in periods of increased illegal activity. On the other hand, there are concerns about the alleged social and ethical implications of using drones with coercive purposes [155]. Duffy debated the advent of militarized conservation and stated that drones and similar technologies could contribute to human rights breaching [156], which may lessen the commitment of native communities $[36,157]$ to protect their natural resources. Under these considerations, more research is needed to identify those technological advances and best practices that do not pose or minimize the risk to the privacy and welfare of people but serve for the purpose of surveillance. In this sense, thermal images reveal the temperature profile of the target, but lack the ability to collect sensitive personal information. Other measures can be taken to restrict the surveillance to previously defined zones and according to poaching threat maps [158] representing those areas with greatest pressures. In addition, some studies have remarked that the effectiveness of antipoaching depends on a greater allocation of resources [144]. For example, to improve the effectiveness of offshore guarding activities [159], patrol vessel could acquire waterproof rotary-wing or fixed-wing drones with float planes to persuade and record illegal fishing within the boundaries of marine protected areas. These evidences could be considered a reliable proof in court, even when offenders are seized outside the no-take zones [160]. Alternatively, there are some reported experiences where drones assisted counter-mapping with reasonable success [161,162]. With all due caution, these are some compelling reasons to encourage the development and implementation of drones to fight poaching. Nevertheless, the success of such initiatives might require a greater consensus among the parties involved and the development of multidisciplinary strategies that seek to solve these recurrent threats to biodiversity.

\subsubsection{Ecotourism}

Well-managed ecotourism promotes conservation and provides socioeconomic benefits to local communities. Otherwise, it may adversely affect the welfare of the animals and disrupt their habitats [163]. In the midst of the dilemma, drones have been proposed for recreational and educational purposes [164,165], document natural monuments and cultural sites [166]; and social 
research and visitor surveillance $[167,168]$. However, drone operations are susceptible to endanger wildlife [35], compromise tourist experience [153] or in case of accidents, lead to pollution or wildfires in sensitive areas due to the presence of toxic and flammable components. Subsequently, to restrain the uncontrolled presence of drones in protected areas, stakeholders agreed on a set of policies to establish permitted activities in Antarctica [169], opted for simpler rules and recommendations [170] or completely banned drones arguing safety reasons and wildlife impact [171]. Even when the economic benefits and leisure possibilities are promising, undesirable events and a lack of ethical practices could emphasize the negative connotations of drones to the detriment of their advantages. Thus, it would be advisable to be cautious in the face of a growing demand to incorporate drones into ecotourism services and continue working on a set of consensual measures to minimize the potential drawbacks drones may bring to protected areas.

\subsubsection{Environmental Management and Disaster Response}

Effectively managing protected areas requires continuous monitoring of environmental biophysical indicators to ensure that potential sources of contamination are controlled or below a safety threshold and, if necessary, take appropriate restoration measures. In many cases, a rapid response is crucial to diminish the effects that natural and man-made disasters pose to natural resources and human beings. Usually, these conservation actions combine fieldwork, airborne and satellite remote sensing. Drone capabilities provide a fine-scale alternative to remotely assist water, soil and air quality sampling [172-176], and enable rapid image acquisition to monitor erosion [177]; sediments dynamics [178,179]; forest windthrow [180]; habitat degradation [125]; landslides [181-183]; flood [184]; volcanic events [183,185,186]; oil spills [187]; and wildfires [188-190] at different stages. Drones may also serve as valuable tools for rangers in search and rescue missions in marine and remote mountainous regions [191,192]. Besides, there are a variety of plausible scenarios where drones can prove to be useful, such as detecting marine litter [193-195], inspect facilities [196]; collect information gathered from environmental sensor networks [197]; or support plant invasion monitoring [198] and control by means of aerially deployed herbicide on targeted species [199].

\subsection{Current Challenges on the Integration of Drones in Protected Areas}

\subsubsection{Legal Barriers and Ethical Constraints}

Drone operations face important social and legal barriers that undermine their potential in the civilian sphere $[36,200,201]$. Not without founded reasons, an overly restrictive and indiscriminate regulatory framework arguing privacy and safety issues is currently limiting the applications of drones in the field of conservation. This highlights the urgent need to seek consensus among countries and adapt legislation to distinguish between the purpose of leisure, research and management [202].

\subsubsection{Impact of Drones on Wildlife and Ecosystems}

Animal welfare and alteration of sensitive habitat in wildlife management and ecological research is a source of strong debate $[203,204]$. Some authors have reported disturbance effects of drones on birds [57,205-209], reptiles [210] and mammals [211-213]. Despite a greater degree of awareness reflected in a emergent set of guidelines to minimize the impacts on wildlife [35,56,214,215], most studies marginally inform reactions and further trials aimed at quantifying changes in behavioral patterns and physiological effects targeting a broader group of species is recommended. An optimal trade-off between benefits and environmental costs should be weighed [216,217]. By designing quieter, non-polluting and safer components, along with following up the suggested flight patterns, the impact on wildlife and ecosystems could be reduced and its objective and unbiased observation facilitated $[47,204]$. Therefore, drones have great potential to evolve, replacing more invasive monitoring techniques. This should be consciously considered by those reluctant to integrate drones in research and conservation activities. Step by step, a code of best practice and recommendations 
could be continuously updated based on lessons learned [206], forming the basis for wildlife certified drone operators [35].

\subsubsection{Costs of Drone Operation}

Expenses derived from using drones in the long term are difficult to quantify [218] and depend on a confluence of factors. Some of the applications described above rely on the acquisition of sophisticated on-board instruments, devices and sensors, advanced communications system or gas-powered engines for longer endurance and heavier payloads. The large volume of data collected must be conveniently stored and processed, which often require qualified staff and adequate IT (Information Technology) infrastructures. In addition, operations with drones are not exempt from accidents, which may compromise the viability of some projects. The payload is usually the most expensive part of the platform, and this often breaks down. Park managers should be aware that there is not a single solution covering all the conservation purposes [219] and a trade-off analysis among available platforms and sensors should be pondered. In this regard, do-it-yourself (DIY) drones can be equipped with a flexible array of sensors and according to very specific requirements, but extra time and experience is required for the correct assemblage and configuration of parts. Since ready to fly commercial platforms are tested and proven systems, it could be argued that they present more reliable capabilities than custom-built drones. Moreover, the consumer market shows a gradual drop on prices in higher performance platforms [220]. Suppliers often provide support, training and companion software, albeit services could be occasionally charged. Nonetheless, there is general agreement that costs associated with drones are lower compared to established methods (Table 3), such as manned aircraft and ground incursions $[13,178,211]$, at least for mapping small and medium scale areas. Although the benefits of monitoring greater extensions with drones remain challenging according to the state of the art, the situation is likely to be more favorable with the advent of more efficient aerial platforms.

Table 3. Examples of studies reporting favorable use of drones compared with established methods.

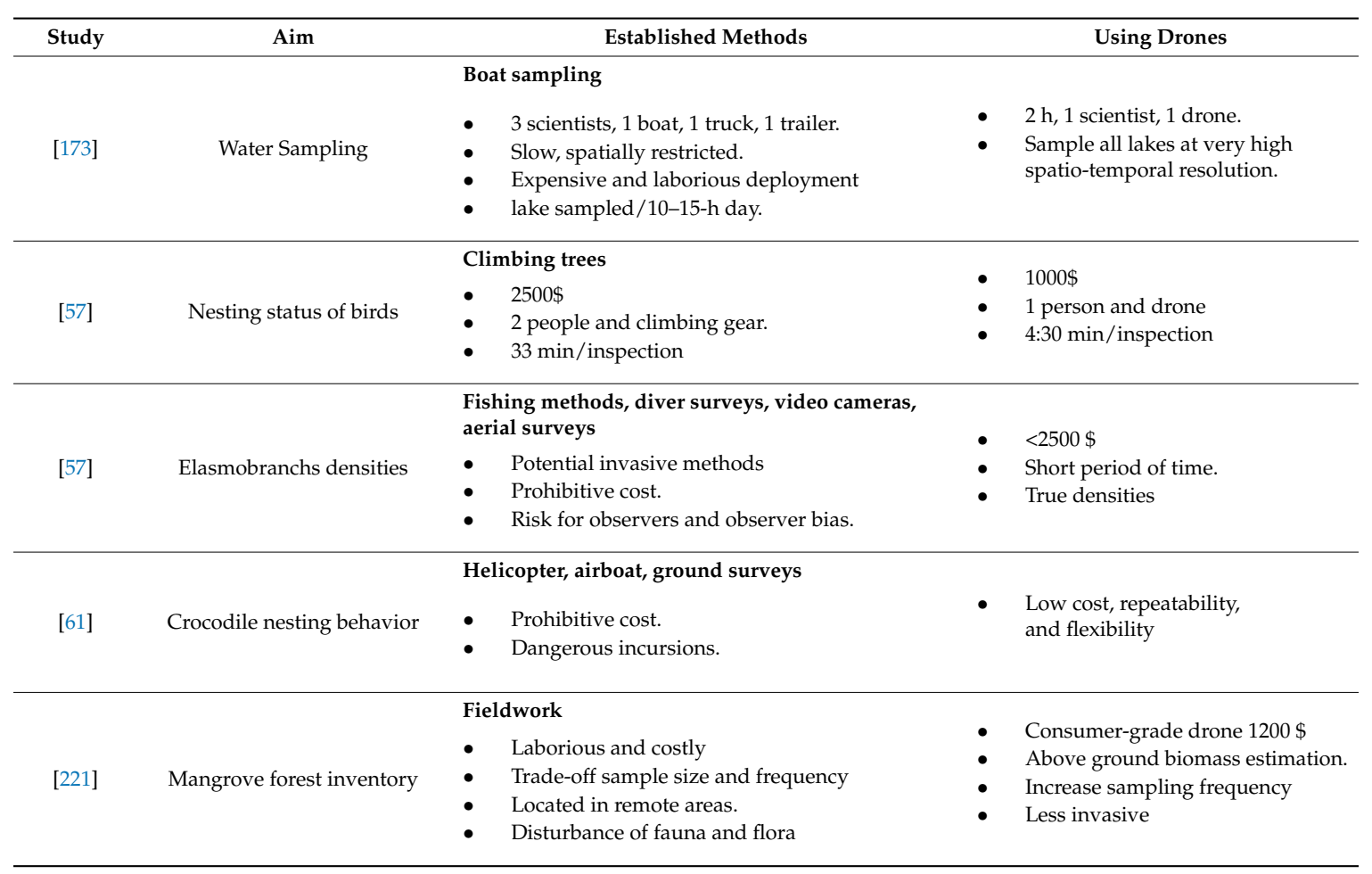




\subsubsection{Technological Challenges}

As previously noted, the massive volume of data that sensors collect in the course of the surveys need to be stored, processed and analyzed, causing severe procedural bottlenecks [6] that need to be solved. When using aerial images for wildlife census, the manual counting and identification of individuals represent a considerable investment in time and costs. Progress in computer vision and machine learning are intended to automate such routine tasks [52,81,222-228]. Despite encouraging results [229], these methods are only available for relatively easy to spot species in open natural environments and require highly qualified personnel to offer reliable results. In addition, further research is required to assess the overall performance of drone data collection techniques to address the analysis and modelling of species distribution, especially in comparison with more mature statistical and sampling methods [58]. On the other hand, traditional pixel-based algorithms are rather inefficient when processing very high resolution images [128]. Therefore, object-based image analysis (OBIA) and deep learning techniques [230] will likely prevail during the next generation of land-cover, habitat and vegetation classification methods [8]. The arrival of affordable hyperspectral miniaturized sensors $[124,128,231,232]$, will bring more complexity to the matter, requiring novel analytical approaches not currently implemented. Conversely, the entire photogrammetric process is well documented [233] and supported by commercial desktop and mobile applications, but also open source solutions [21], probably at expense of a major level of expertise [234,235]. Drones using Real Time Kinematic (RTK) and Post Processing Kinematic (PPK) techniques can produce survey-grade maps without requiring labor intensive ground control points (GCPs). Yet, the radiometric calibration of aerial images requires additional improvements [37] since it is considered a crucial step to carry out multi-temporal studies [236]. The confluence of big data [237], networked drones [238,239], artificial intelligence and sensors will bring new unforeseen perspectives to conservation, but integration of products and services to deliver off-the-shelf management solutions are still in their infancy.

\subsection{Linking Drone Platforms and Sensors with Conservation}

Park managers considering the acquisition of drones may need expert guidance to select the most suitable platform and sensor for each purpose. Here we provide a brief summary of most common imaging and ranging sensors (Table 4). Consumer grade cameras are adequate for general mapping and photogrammetric tasks. Sensor size, focal length and lens quality are the main camera factors that influence the accuracy of the survey. More advance remote sensing applications require the adoption of multispectral and hyperspectral sensors. The former encompasses both modified RGB cameras to near infrared and multispectral cameras with great prospects for precision agriculture, forestry and a broad range of vegetation studies [240]. Hyperspectral sensors collect information in multiple bands across the electromagnetic spectrum, and are of great interest to remotely observe the spectral response of many distinct biophysical parameters [22] and physiological process of organisms [124]. These families of sensors require radiometric calibration to account for variable lighting conditions and retrieve physical quantities that can be compared in time and with other sensors [241]. Thermal infrared cameras can remotely sense heat even in low visibility conditions and are ordinarily used for industrial inspection and surveillance, but also in soil science [242] and animal ecology [64]. Thermal sensitivity, expressed as the ability of the sensor to discriminate differences of temperatures even in low contrast scenes, is one of the most important technical aspects to increase the detection rate of wildlife [52]. LiDAR instruments are relatively expensive active sensors that can penetrate the canopy and derive accurate three-dimensional forest metrics and terrain models. However, structure-from-motion (SfM) [243] imaging techniques based on standard RGB cameras represent a low-cost alternative with limited, but reasonable results. In terms of platforms, long-endurance fixed-wing drones are preferred when surveying large areas and when landing is not a problem. Conversely, rotary-wing platforms are more versatile, and can operate in a diverse range of situations where precise flights prove more advantageous, such as in confined spaces and close-range inspection tasks, marine settings and terrestrial areas with steep terrain, or extensive vegetation cover. 
Table 4. Suitable sensors for research and management tasks.

\begin{tabular}{ll}
\hline Sensor & Applications \\
\hline Visible RGB & $\begin{array}{l}\text { Aerial photography, habitat mapping, photogrammetry, 3D Modeling, } \\
\text { inspection, wildlife surveys (identification), landslides }\end{array}$ \\
\hline Multispectral & Vegetation indices, productivity, water quality, geological surveys \\
\hline Hyperspectral & $\begin{array}{l}\text { Vegetation studies, biophysical variables, ecological processes, forest health, } \\
\text { chlorophyll content, insect outbreaks. }\end{array}$ \\
\hline Thermal & $\begin{array}{l}\text { Inspection, wildlife surveys (detection), surveillance, wildfires, soil temperature, } \\
\text { volcanology }\end{array}$ \\
\hline LiDAR & $\begin{array}{l}\text { 3D Modeling, topographical maps, forest inventory and metrics } \\
\text { (structure, biomass, tree volume, canopy height, leaf area index) }\end{array}$ \\
\hline
\end{tabular}

\subsection{Knowledge Gaps and Recommendations for Future Research}

The variety of information gathered from drones represents a great opportunity to complement ongoing Earth Observation programs aimed to monitor anthropogenic pressures threatening the ecological integrity of protected areas [244]. Drones can be rapidly deployed there, where early sign of disturbance have been previously detected using satellite images and environmental sensor networks [245]. Although many protected areas are too large to be mapped using drones, there are small, inaccessible and environmentally sensitive terrestrial and marine areas (ESAs) with important ecological values that could take advantage from drones. Once the use of drones has proven feasible in many different fields of application, it would be of interest that research focuses on methods to produce a set of ecological indicators in line with established monitoring frameworks [246]. For example, a wide range of biodiversity metrics, ecosystem processes and natural and anthropogenic stressors could be measured or derived, but further efforts are required to transfer advances on the field into accessible products for direct use at management levels. Table 5 suggest some potential challenges that can help to guide future research in the field.

Table 5. Challenges for the effective implementation of drones in protected areas.

\begin{tabular}{|c|c|}
\hline $\begin{array}{c}\text { Management } \\
\text { Categories }\end{array}$ & Challenges \\
\hline $\begin{array}{l}\text { Wildlife Research and } \\
\text { Management }\end{array}$ & $\begin{array}{l}\text { - } \quad \text { Development of drones to minimize impact of wildlife. } \\
\text { - } \quad \text { Optimization of automatic pattern recognition algorithms. } \\
\text { - } \quad \text { Integrating movement and visible/thermal data. } \\
\text { - } \quad \text { Population structure and function, wildlife traits. }\end{array}$ \\
\hline Ecotourism & $\begin{array}{ll}\text { - } & \text { Cost/benefit analysis } \\
\text { - } & \text { Potential to introduce virtual flights. } \\
\text { - } & \text { Fine-scale geofencing maps (Detailed map of sites where drone flights are allowed/conditioned/restricted) }\end{array}$ \\
\hline $\begin{array}{l}\text { Environmental } \\
\text { Management and } \\
\text { Disaster Response }\end{array}$ & $\begin{array}{l}\text { - } \quad \text { Move from prototypes to products and services. } \\
\text { - } \quad \text { Implementation of Regional/Global Infrastructures for decision support. } \\
\text { - } \quad \text { Satellite/Drone Remote Sensing integrative approach to model disturbance regimes. }\end{array}$ \\
\hline
\end{tabular}


Supplementary Materials: The following are available online at http:/ www.mdpi.com/2504-446X/3/1/10/s1, Figure S1. PRISMA Flowchart; Table S1. List of studies.

Author Contributions: J.J.L. and M.M.P conceived and designed the study; J.J.L. collected and analyzed the studies; J.J.L. and M.M.P wrote the manuscript.

Funding: This research received no external funding.

Acknowledgments: The authors would like to thank the Editorial Office, and anonymous reviewers for their valuable comments and suggestions.

Conflicts of Interest: The authors declare no conflict of interest.

\section{References}

1. Dudley, N. Guidelines for Protected Area Management Categories; IUCN: Gland, Switzerland, 2008; Volume 3, ISBN 978-2-8317-1086-0.

2. Watson, J.E.M.; Dudley, N.; Segan, D.B.; Hockings, M. The performance and potential of protected areas. Nature 2014, 515, 67-73. [CrossRef] [PubMed]

3. Juffe-Bignoli, D.; Burgess, N.D.; Bingham, H.; Belle, E.M.S.; de Lima, M.G.; Deguignet, M.; Bertzky, B.; Milam, N.; Martinez-Lopez, J.; Lewis, E.; et al. Protected Planet Report 2014; UNEP-WCMC: Cambridge, UK, 2014; ISBN 9789280734164.

4. Gonçalves, J.; Henriques, R.; Alves, P.; Sousa-Silva, R.; Monteiro, A.T.; Lomba, Â.; Marcos, B.; Honrado, J. Evaluating an unmanned aerial vehicle-based approach for assessing habitat extent and condition in fine-scale early successional mountain mosaics. Appl. Veg. Sci. 2016, 19, 132-146. [CrossRef]

5. Lopoukhine, N.; Crawhall, N.; Dudley, N.; Figgis, P.; Karibuhoye, C.; Laffoley, D.; Londoño, J.M.; MacKinnon, K.; Sandwith, T. Protected areas: providing natural solutions to 21st Century challenges. Surveys and Perspectives Integrating Environment and Society 2012, 5, 1-16. [CrossRef]

6. Pimm, S.L.; Alibhai, S.; Bergl, R.; Dehgan, A.; Giri, C.; Jewell, Z.; Joppa, L.; Kays, R.; Loarie, S. Emerging technologies to conserve biodiversity. Trends Ecol. Evol. 2015, 30, 685-696. [CrossRef] [PubMed]

7. Melesse, A.; Weng, Q.; Prasad, S.; Senay, G. Remote Sensing Sensors and applications in environmental resources mapping and modelling. Sensors 2007, 7, 3209-3241. [CrossRef] [PubMed]

8. Whitehead, K.; Hugenholtz, C.H. Remote sensing of the environment with small unmanned aircraft systems (UASs), part 1: A review of progress and challenges. J. Unmanned Veh. Syst. 2014, 2, 69-85. [CrossRef]

9. Rodríguez, A.; Negro, J.J.; Mulero, M.; Rodríguez, C.; Hernández-Pliego, J.; Bustamante, J. The Eye in the Sky: Combined Use of Unmanned Aerial Systems and GPS Data Loggers for Ecological Research and Conservation of Small Birds. PLoS One 2012, 7. [CrossRef]

10. Linchant, J.; Lisein, J.; Semeki, J.; Lejeune, P.; Vermeulen, C. Are unmanned aircraft systems (UASs) the future of wildlife monitoring? A review of accomplishments and challenges. Mamm. Rev. 2015, 45, 239-252. [CrossRef]

11. Christie, K.S.; Gilbert, S.L.; Brown, C.L.; Hatfield, M.; Hanson, L. Unmanned aircraft systems in wildlife research: Current and future applications of a transformative technology. Front. Ecol. Environ. 2016, 14, 241-251. [CrossRef]

12. Mulero-Pázmány, M.; Stolper, R.; Van Essen, L.D.; Negro, J.J.; Sassen, T. Remotely piloted aircraft systems as a rhinoceros anti-poaching tool in Africa. PLoS One 2014, 9, 1-10. [CrossRef]

13. Koh, L.P.; Wich, S.A. Dawn of drone ecology: low-cost autonomous aerial vehicles for conservation. Trop. Conserv. Sci. 2012, 5, 121-132. [CrossRef]

14. Chabot, D.; Bird, D.M. Wildlife research and management methods in the 21st century: Where do unmanned aircraft fit in? J. Unmanned Veh. Syst. 2015, 3, 137-155. [CrossRef]

15. Schofield, G.; Katselidis, K.A.; Lilley, M.K.S.; Reina, R.D.; Hays, G.C. Detecting elusive aspects of wildlife ecology using drones: new insights on the mating dynamics and operational sex ratios of sea turtles. Funct. Ecol. 2017, 38, 42-49. [CrossRef]

16. Näsi, R.; Honkavaara, E.; Lyytikäinen-Saarenmaa, P.; Blomqvist, M.; Litkey, P.; Hakala, T.; Viljanen, N.; Kantola, T.; Tanhuanpää, T.; Holopainen, M. Using UAV-based photogrammetry and hyperspectral imaging for mapping bark beetle damage at tree-level. Remote Sens. 2015, 7, 15467-15493. [CrossRef] 
17. Wang, D.; Xin, X.; Shao, Q.; Brolly, M.; Zhu, Z.; Chen, J. Modeling aboveground biomass in Hulunber grassland ecosystem by using unmanned aerial vehicle discrete lidar. Sensors 2017, 17, 180. [CrossRef] [PubMed]

18. Villa, T.; Gonzalez, F.; Miljievic, B.; Ristovski, Z.; Morawska, L. An overview of small unmanned aerial vehicles for air quality measurements: Present applications and future prospectives. Sensors 2016, 16, 1072. [CrossRef] [PubMed]

19. Pádua, L.; Vanko, J.; Hruška, J.; Adão, T.; Sousa, J.J.; Peres, E.; Morais, R. UAS, sensors, and data processing in agroforestry: a review towards practical applications. Int. J. Remote Sens. 2017, 38, 2349-2391. [CrossRef]

20. Hassanalian, M.; Abdelkefi, A. Classifications, applications, and design challenges of drones: A review. Prog. Aerosp. Sci. 2017, 91, 99-131. [CrossRef]

21. Colomina, I.; Molina, P. Unmanned aerial systems for photogrammetry and remote sensing: A review. ISPRS J. Photogramm. Remote Sens. 2014, 92, 79-97. [CrossRef]

22. Adão, T.; Hruška, J.; Pádua, L.; Bessa, J.; Peres, E.; Morais, R.; Sousa, J. Hyperspectral imaging: A review on uav-based sensors, data processing and applications for agriculture and forestry. Remote Sens. 2017, 9, 1110. [CrossRef]

23. Brown, A. Grand Canyon Park Rangers Use Drones to Search for Missing Hikers. Available online: http:/ / www.thedrive.com/aerial/9619/grand-canyon-park-rangers-use-drones-to-search-formissing-hikers?\# (accessed on 27 September 2018).

24. Margaritoff, M. Australian Rangers Use Drones to Monitor and Protect Endangered Turtles From Predators. Available online: http:/ / www.thedrive.com/tech/22747/australian-rangers-use-drones-to-monitor-andprotect-endangered-turtles-from-predators (accessed on 26 September 2018).

25. Richmond, B.C. Drones, dogs and DNA the latest weapons against invasive species. Available online: https:/ / www.theglobeandmail.com/news/national/drones-dogs-and-dna-the-latest-weaponsagainst-invasive-species/article28531824/ (accessed on 27 September 2018).

26. Beaubien, J. Eyes In The Sky: Foam Drones Keep Watch On Rain Forest Trees. Available online: https:/ / www.npr.org/sections/goatsandsoda/2015/05/19/398765759/eyes-in-the-sky-styrofoamdrones-keep-watch-on-rainforest-trees?t=1540327094055 (accessed on 28 September 2018).

27. Crooks, J. Drone Collects Information to Benefit Great Lakes. Available online: https://www.fs.fed.us / blogs / drone-collects-information-benefit-great-lakes (accessed on 27 September 2018).

28. Nuwer, R. High Above, Drones Keep Watchful Eyes on Wildlife in Africa. Available online: https://www. nytimes.com/2017/03/13/science/drones-africa-poachers-wildlife.html (accessed on 27 September 2018).

29. Kohler, P. Launching the Marine Litter DRONET. Available online: https:/ / www.theplastictide.com/blog1/2018/4/22/launching-the-marine-litter-dronet (accessed on 22 September 2018).

30. Cirino, E. Drones Help Find Massive Penguin Colonies Hiding in Plain Sight. Available online: https:/ / www.newsdeeply.com/oceans/articles/2018/03/05/drones-help-find-massive-penguincolonies-hiding-in-plain-sight (accessed on 18 September 2018).

31. DRONE HOPPER, S.L. Drone Hopper I Firefigthing Drone. Available online: https:/ /www.drone-hopper. com/home (accessed on 2 September 2018).

32. Apprill, A.; Miller, C.A.; Moore, M.J.; Durban, J.W.; Fearnbach, H.; Barrett-Lennard, L.G. Extensive Core Microbiome in Drone-Captured Whale Blow Supports a Framework for Health Monitoring. mSystems 2017. [CrossRef] [PubMed]

33. Foxx, C. Drones scatter mosquitoes to fight diseases. Available online: https://www.bbc.co.uk/news/ technology-42066518 (accessed on 21 September 2018).

34. Stone, E. Drones Spray Tree Seeds From the Sky to Fight Deforestation. Available online: https://news. nationalgeographic.com/2017/11/drones-plant-trees-deforestation-environment/?user.testname=none (accessed on 21 September 2018).

35. Mulero-Pázmány, M.; Jenni-Eiermann, S.; Strebel, N.; Sattler, T.; Negro, J.J.; Tablado, Z. Unmanned aircraft systems as a new source of disturbance for wildlife: A systematic review. PLoS One 2017, 12, e0178448. [CrossRef] [PubMed]

36. Sandbrook, C. The social implications of using drones for biodiversity conservation. Ambio 2015, 44, 636-647. [CrossRef] 
37. Manfreda, S.; McCabe, M.F.; Miller, P.E.; Lucas, R.; Madrigal, V.P.; Mallinis, G.; Ben Dor, E.; Helman, D.; Estes, L.; Ciraolo, G.; et al. On the use of unmanned aerial systems for environmental monitoring. Remote Sens. 2018, 10. [CrossRef]

38. Bruner, A.G. Effectiveness of parks in protecting tropical biodiversity. Science 2001, 291, 125-128. [CrossRef] [PubMed]

39. Leverington, F.; Costa, K.L.; Courrau, J.; Pavese, H.; Nolte, C.; Marr, M.; Coad, L.; Burgess, N.; Bomhard, B.; Hockings, M.; et al. Management effectiveness evaluation in protected areas-A global study. Second edition 2010. Environ. Manage. 2010, 46, 685-698. [CrossRef]

40. Avramovic Danijela Evaluation of protected area management effectiveness-An overview of methodologies. Saf. Eng. 2016, 6, 29-35. [CrossRef]

41. UNEP-WCMC; IUCN Protected Planet: The World Database on Protected Areas (WDPA)/The Global Database on Protected Areas Management Effectiveness (GD-PAME). Available online: https://www. protectedplanet.net (accessed on 22 October 2018).

42. Olson, D.M.; Dinerstein, E.; Wikramanayake, E.D.; Burgess, N.D.; Powell, G.V.N.; Underwood, E.C.; D'amico, J.A.; Itoua, I.; Strand, H.E.; Morrison, J.C.; et al. Terrestrial Ecoregions of the World: A New Map of Life on Earth. Bioscience 2001. [CrossRef]

43. Stoll-Kleemann, S. Evaluation of management effectiveness in protected areas: Methodologies and results. Basic Appl. Ecol. 2010, 11, 377-382. [CrossRef]

44. Salafsky, N.; Salzer, D.; Stattersfield, A.J.; Hilton-Taylor, C.; Neugarten, R.; Butchart, S.H.M.; Collen, B.; Cox, N.; Master, L.L.; O'Connor, S.; et al. A standard lexicon for biodiversity conservation: Unified classifications of threats and actions. Conserv. Biol. 2008, 22, 897-911. [CrossRef]

45. Sasse, D.B. Job-related mortality of wildlife workers in the United States, 1937-2000. Wildl. Soc. Bull. 2003, 31, 1000-1003.

46. Lubow, B.C.; Ransom, J.I. Practical bias correction in aerial surveys of large mammals: Validation of hybrid double-observer with sightability method against known abundance of feral horse (Equus caballus) populations. PLoS One 2016. [CrossRef] [PubMed]

47. Jewell, Z. Effect of Monitoring Technique on Quality of Conservation Science. Conserv. Biol. 2013, 27, 501-508. [CrossRef] [PubMed]

48. Chrétien, L.-P.; Théau, J.; Ménard, P. Visible and thermal infrared remote sensing for the detection of white-tailed deer using an unmanned aerial system. Wildl. Soc. Bull. 2016, 40, 181-191. [CrossRef]

49. Wich, S.; Dellatore, D.; Houghton, M.; Ardi, R.; Koh, L.P. A preliminary assessment of using conservation drones for Sumatran orangutan (Pongo abelii) distribution and density. J. Unmanned Veh. Syst. 2016, 4, 45-52. [CrossRef]

50. Stark, D.J.; Vaughan, I.P.; Evans, L.J.; Kler, H.; Goossens, B. Combining drones and satellite tracking as an effective tool for informing policy change in riparian habitats: A proboscis monkey case study. Remote Sens. Ecol. Conserv. 2017, 1-9. [CrossRef]

51. Sweeney, K.L.; Helker, V.T.; Perryman, W.L.; LeRoi, D.J.; Fritz, L.W.; Gelatt, T.S.; Angliss, R.P. Flying beneath the clouds at the edge of the world: using a hexacopter to supplement abundance surveys of Steller sea lions (Eumetopias jubatus) in Alaska. J. Unmanned Veh. Syst. 2016, 4, 70-81. [CrossRef]

52. Seymour, A.C.; Dale, J.; Hammill, M.; Halpin, P.N.; Johnston, D.W. Automated detection and enumeration of marine wildlife using unmanned aircraft systems (UAS) and thermal imagery. Sci. Rep. 2017, 7, 45127. [CrossRef]

53. Hodgson, A.; Peel, D.; Kelly, N. Unmanned aerial vehicles for surveying marine fauna: assessing detection probability. Ecol. Appl. 2017, 27, 1253-1267. [CrossRef]

54. Torres, L.G.; Nieukirk, S.L.; Lemos, L.; Chandler, T.E. Drone Up! Quantifying Whale Behavior From a New Perspective Improves Observational Capacity. Front. Mar. Sci. 2018, 5, 1-14. [CrossRef]

55. Pirotta, V.; Smith, A.; Ostrowski, M.; Russell, D.; Jonsen, I.D.; Grech, A.; Harcourt, R. An Economical Custom-Built Drone for Assessing Whale Health. Front. Mar. Sci. 2017, 4, 1-12. [CrossRef]

56. Junda, J.; Greene, E.; Bird, D.M. Proper flight technique for using a small rotary-winged drone aircraft to safely, quickly, and accurately survey raptor nests. J. Unmanned Veh. Syst. 2015, 3, 222-236. [CrossRef]

57. Weissensteiner, M.H.; Poelstra, J.W.; Wolf, J.B.W. Low-budget ready-to-fly unmanned aerial vehicles: An effective tool for evaluating the nesting status of canopy-breeding bird species. J. Avian Biol. 2015, 46, 425-430. [CrossRef] 
58. Hodgson, J.C.; Baylis, S.M.; Mott, R.; Herrod, A.; Clarke, R.H. Precision wildlife monitoring using unmanned aerial vehicles. Sci. Rep. 2016, 6, 22574. [CrossRef] [PubMed]

59. Sardà-Palomera, F.; Bota, G.; Padilla, N.; Brotons, L.; Sardà, F. Unmanned aircraft systems to unravel spatial and temporal factors affecting dynamics of colony formation and nesting success in birds. J. Avian Biol. 2017. [CrossRef]

60. Han, Y.G.; Yoo, S.H.; Kwon, O. Possibility of applying unmanned aerial vehicle (UAV) and mapping software for the monitoring of waterbirds and their habitats. J. Ecol. Environ. 2017, 41, 1-7. [CrossRef]

61. Evans, L.J.; Jones, T.H.; Pang, K.; Evans, M.N.; Saimin, S.; Goossens, B. Use of drone technology as a tool for behavioral research: A case study of crocodilian nesting. Herpetol. Conserv. Biol. 2015, 10, 90-98. [CrossRef]

62. Elsey, R.M.; Trosclair, P.L., III. the use of an unmanned aerial vehicle to locate alligator nests. Southeast. Nat. 2016, 15, 76-82. [CrossRef]

63. Sykora-Bodie, S.T.; Bezy, V.; Johnston, D.W.; Newton, E.; Lohmann, K.J. Quantifying Nearshore Sea Turtle Densities: Applications of Unmanned Aerial Systems for Population Assessments. Sci. Rep. 2017, 7, 1-7. [CrossRef]

64. Rees, A.; Avens, L.; Ballorain, K.; Bevan, E.; Broderick, A.; Carthy, R.; Christianen, M.; Duclos, G.; Heithaus, M.; Johnston, D.; et al. The potential of unmanned aerial systems for sea turtle research and conservation: a review and future directions. Endanger. Species Res. 2018, 35, 81-100. [CrossRef]

65. Groves, P.A.; Alcorn, B.; Wiest, M.M.; Maselko, J.M.; Connor, W.P. Testing unmanned aircraft systems for salmon spawning surveys. Facets 2016, 1, 187-204. [CrossRef]

66. Kiszka, J.J.; Mourier, J.; Gastrich, K.; Heithaus, M.R. Using unmanned aerial vehicles (UAVs) to investigate shark and ray densities in a shallow coral lagoon. Mar. Ecol. Prog. Ser. 2016, 560, 237-242. [CrossRef]

67. Kellenberger, B.; Marcos, D.; Tuia, D. Detecting mammals in UAV images: Best practices to address a substantially imbalanced dataset with deep learning. Remote Sens. Environ. 2018, 216, 139-153. [CrossRef]

68. Wilson, A.M.; Barr, J.; Zagorski, M. The feasibility of counting songbirds using unmanned aerial vehicles. Auk 2017, 134, 350-362. [CrossRef]

69. Mulero-Pázmány, M.; Barasona, J.Á.; Acevedo, P.; Vicente, J.; Negro, J.J. Unmanned Aircraft Systems complement biologging in spatial ecology studies. Ecol. Evol. 2015, 5, 4808-4818. [CrossRef] [PubMed]

70. Tremblay, J.A.; Desrochers, A.; Aubry, Y.; Pace, P.; Bird, D.M. A Low-Cost Technique for Radio-Tracking Wildlife Using a Small Standard Unmanned Aerial Vehicle. J. Unmanned Veh. Syst. 2016, juvs-2016-0021. [CrossRef]

71. Ivosevic, B.; Han, Y.-G.; Kwon, O. Monitoring butterflies with an unmanned aerial vehicle: current possibilities and future potentials. J. Ecol. Environ. 2017, 41, 12. [CrossRef]

72. Habel, J.C.; Teucher, M.; Ulrich, W.; Bauer, M.; Rödder, D. Drones for butterfly conservation: larval habitat assessment with an unmanned aerial vehicle. Landsc. Ecol. 2016, 31, 2385-2395. [CrossRef]

73. Kim, H.G.; Park, J.-S.; Lee, D.-H. Potential of Unmanned Aerial Sampling for Monitoring Insect Populations in Rice Fields. Florida Entomol. 2018, 101, 330-334. [CrossRef]

74. Ogra, M.V. Human-wildlife conflict and gender in protected area borderlands: A case study of costs, perceptions, and vulnerabilities from Uttarakhand (Uttaranchal), India. Geoforum 2008. [CrossRef]

75. Hahn, N.; Mwakatobe, A.; Konuche, J.; de Souza, N.; Keyyu, J.; Goss, M.; Chang'a, A.; Palminteri, S.; Dinerstein, E.; Olson, D. Unmanned aerial vehicles mitigate human-elephant conflict on the borders of Tanzanian Parks: a case study. Oryx 2017, 51, 513-516. [CrossRef]

76. Michez, A.; Morelle, K.; Lehaire, F.; Widar, J.; Authelet, M.; Vermeulen, C.; Lejeune, P.; Michez, A.; Morelle, K.; Lehaire, F; et al. Use of unmanned aerial system to assess wildlife (Sus scrofa) damage to crops (Zea mays). J. Unmanned Veh. Sys 2016, 4, 266-275. [CrossRef]

77. Johnston, M.; McCaldin, G.; Rieker, A. Assessing the availability of aerially-delivered baits to feral cats through rainforest canopy using unmanned aircraft. 2016. [CrossRef]

78. Mulero-Pázmány, M.; Negro, J.J.; Ferrer, M. A low cost way for assessing bird risk hazards in power lines: Fixed-wing small unmanned aircraft systems. J. Unmanned Veh. Syst. 2014, 02, 5-15. [CrossRef]

79. Lobermeier, S.; Moldenhauer, M.; Peter, C.; Slominski, L.; Tedesco, R.; Meer, M.; Dwyer, J.; Harness, R.; Stewart, A. Mitigating avian collision with power lines: a proof of concept for installation of line markers via unmanned aerial vehicle. J. Unmanned Veh. Syst. 2015, 3, 252-258. [CrossRef]

80. Israel, M. A UAV-based roe deer fawm detection system. Int. Arch. Photogramm. Remote Sens. Spat. Inf. Sci. 2012, 38, 1-5. [CrossRef] 
81. Christiansen, P.; Steen, K.A.; Jørgensen, R.N.; Karstoft, H. Automated detection and recognition of wildlife using thermal cameras. Sensors 2014, 14, 13778-13793. [CrossRef]

82. Fornace, K.M.; Drakeley, C.J.; William, T.; Espino, F.; Cox, J. Mapping infectious disease landscapes: Unmanned aerial vehicles and epidemiology. Trends Parasitol. 2014, 30, 514-519. [CrossRef]

83. Barasona, J.A.; Mulero-Pázmány, M.; Acevedo, P.; Negro, J.J.; Torres, M.J.; Gortázar, C.; Vicente, J. Unmanned aircraft systems for studying spatial abundance of ungulates: Relevance to spatial epidemiology. PLoS One 2014, 9, 1-17. [CrossRef]

84. Hardy, A.; Makame, M.; Cross, D.; Majambere, S.; Msellem, M. Using low-cost drones to map malaria vector habitats. Parasit. Vectors 2017, 10, 29. [CrossRef]

85. Laguna, E.; Barasona, J.A.; Triguero-Ocaña, R.; Mulero-Pázmány, M.; Negro, J.J.; Vicente, J.; Acevedo, P. The relevance of host overcrowding in wildlife epidemiology: A new spatially explicit aggregation index. Ecol. Indic. 2018, 84, 695-700. [CrossRef]

86. Gibbs, J.P.; Snell, H.L.; Causton, C.E. Effective monitoring for adaptive wildlife management: Lessons from the Galapagos Islands. J. Wildl. Manage. 1999, 63, 1055-1065. [CrossRef]

87. Neumann, W.; Martinuzzi, S.; Estes, A.B.; Pidgeon, A.M.; Dettki, H.; Ericsson, G.; Radeloff, V.C. Opportunities for the application of advanced remotely-sensed data in ecological studies of terrestrial animal movement. Mov. Ecol. 2015. [CrossRef] [PubMed]

88. Whitehead, K.; Hugenholtz, C. Remote Sensing of the Environment with Small Unmanned Aircraft Systems (UASs), Part 2: scientific and commercial applications. J. Unmanned Veh. Syst. 2014, 102, 86-102. [CrossRef]

89. Gross, J.E.; Goetz, S.J.; Cihlar, J. Application of remote sensing to parks and protected area monitoring: Introduction to the special issue. Remote Sens. Environ. 2009, 113, 1343-1345. [CrossRef]

90. Vihervaara, P.; Auvinen, A.P.; Mononen, L.; Törmä, M.; Ahlroth, P.; Anttila, S.; Böttcher, K.; Forsius, M.; Heino, J.; Heliölä, J.; et al. How Essential Biodiversity Variables and remote sensing can help national biodiversity monitoring. Glob. Ecol. Conserv. 2017, 10, 43-59. [CrossRef]

91. Mas, J.F. Assessing protected area effectiveness using surrounding (buffer) areas environmentally similar to the target area. Environ. Monit. Assess. 2005, 105, 69-80. [CrossRef]

92. Ewers, R.M.; Rodrigues, A.S.L. Estimates of reserve effectiveness are confounded by leakage. Trends Ecol. Evol. 2008, 23, 113-116. [CrossRef]

93. Freemantle, T.P.; Wacher, T.; Newby, J.; Pettorelli, N. Earth observation: Overlooked potential to support species reintroduction programmes. Afr. J. Ecol. 2013. [CrossRef]

94. Cress, J.; Hutt, M.; Sloan, J.; Bauer, M.; Feller, M.; Goplen, S. US Geological Survey Unmanned Aircraft Systems (UAS) Roadmap 2014; USGS: Reston, VA, USA, 2015.

95. Puliti, S.; Olerka, H.; Gobakken, T.; Næsset, E. Inventory of Small Forest Areas Using an Unmanned Aerial System. Remote Sens. 2015, 7, 9632-9654. [CrossRef]

96. Michez, A.; Piégay, H.; Lisein, J.; Claessens, H.; Lejeune, P. Classification of riparian forest species and health condition using multi-temporal and hyperspatial imagery from unmanned aerial system. Environ. Monit. Assess. 2016, 188, 1-19. [CrossRef]

97. Tian, J.; Wang, L.; Li, X.; Gong, H.; Shi, C.; Zhong, R.; Liu, X. Comparison of UAV and WorldView-2 imagery for mapping leaf area index of mangrove forest. Int. J. Appl. Earth Obs. Geoinf. 2017, 61, 22-31. [CrossRef]

98. Franklin, S.E.; Ahmed, O.S. Deciduous tree species classification using object-based analysis and machine learning with unmanned aerial vehicle multispectral data. Int. J. Remote Sens. 2017, 39, 5236-5245. [CrossRef]

99. Wallace, L.; Lucieer, A.; Malenovskỳ, Z.; Turner, D.; Vopěnka, P. Assessment of forest structure using two UAV techniques: A comparison of airborne laser scanning and structure from motion (SfM) point clouds. Forests 2016, 7. [CrossRef]

100. Zhang, J.; Hu, J.; Lian, J.; Fan, Z.; Ouyang, X.; Ye, W. Seeing the forest from drones: Testing the potential of lightweight drones as a tool for long-term forest monitoring. Biol. Conserv. 2016, 198, 60-69. [CrossRef]

101. Guo, Q.; Su, Y.; Hu, T.; Zhao, X.; Wu, F.; Li, Y.; Liu, J.; Chen, L.; Xu, G.; Lin, G.; et al. An integrated UAV-borne lidar system for 3D habitat mapping in three forest ecosystems across China. Int. J. Remote Sens. 2017, 38, 2954-2972. [CrossRef]

102. Messinger, M.; Asner, G.P.; Silman, M. Rapid assessments of amazon forest structure and biomass using small unmanned aerial systems. Remote Sens. 2016, 8. [CrossRef]

103. Bedell, E.; Leslie, M.; Fankhauser, K.; Burnett, J.; Wing, M.G.; Thomas, E.A. Unmanned aerial vehicle-based structure from motion biomass inventory estimates. J. Appl. Remote Sens. 2017, 11, 026026. [CrossRef] 
104. Rödig, E.; Cuntz, M.; Heinke, J.; Rammig, A.; Huth, A. Spatial heterogeneity of biomass and forest structure of the Amazon rainforest: linking remote sensing, forest modeling and field inventory. Glob. Ecol. Biogeogr. 2017. [CrossRef]

105. Sankey, T.; Donager, J.; McVay, J.; Sankey, J.B. UAV lidar and hyperspectral fusion for forest monitoring in the southwestern USA. Remote Sens. Environ. 2017, 195, 30-43. [CrossRef]

106. Wilson, A.M.; Silander, J.A.; Gelfand, A.; Glenn, J.H. Scaling up: Linking field data and remote sensing with a hierarchical model. Int. J. Geogr. Inf. Sci. 2011, 25, 509-521. [CrossRef]

107. Chen, J.; Yi, S.; Qin, Y.; Wang, X. Improving estimates of fractional vegetation cover based on UAV in alpine grassland on the Qinghai-Tibetan Plateau. Int. J. Remote Sens. 2016, 37, 1922-1936. [CrossRef]

108. Rivas-Torres, G.F.; Benítez, F.L.; Rueda, D.; Sevilla, C.; Mena, C.F. A methodology for mapping native and invasive vegetation coverage in archipelagos: An example from the Galápagos Islands. Prog. Phys. Geogr. 2018, 42, 83-111. [CrossRef]

109. Szantoi, Z.; Smith, S.E.; Strona, G.; Koh, L.P.; Wich, S.A. Mapping orangutan habitat and agricultural areas using Landsat OLI imagery augmented with unmanned aircraft system aerial photography. Int. J. Remote Sens. 2017, 38, 1-15. [CrossRef]

110. Laliberte, A.S.; Goforth, M.A.; Steele, C.M.; Rango, A. Multispectral remote sensing from unmanned aircraft: Image processing workflows and applications for rangeland environments. Remote Sens. 2011, 3, 2529-2551. [CrossRef]

111. Iqbal, F.; Lucieer, A.; Barry, K. Simplified radiometric calibration for UAS-mounted multispectral sensor. Eur. J. Remote Sens. 2018. [CrossRef]

112. Paneque-Gálvez, J.; McCall, M.K.; Napoletano, B.M.; Wich, S.A.; Koh, L.P. Small drones for community-based forest monitoring: An assessment of their feasibility and potential in tropical areas. Forests 2014, 5, 1481-1507. [CrossRef]

113. Mlambo, R.; Woodhouse, I.H.; Gerard, F.; Anderson, K. Structure from motion (SfM) photogrammetry with drone data: A low cost method for monitoring greenhouse gas emissions from forests in developing countries. Forests 2017, 8. [CrossRef]

114. Hill, D.J.; Tarasoff, C.; Whitworth, G.E.; Baron, J.; Bradshaw, J.L.; Church, J.S. Utility of unmanned aerial vehicles for mapping invasive plant species: a case study on yellow flag iris (Iris pseudacorus L.). Int. J. Remote Sens. 2017, 38, 2083-2105. [CrossRef]

115. Müllerová, J.; Brůna, J.; Dvořák, P.; Bartaloš, T.; Vítková, M. Does the data resolution/origin matter? Satellite, airborne and UAV imagery to tackle plant invasions. Int. Arch. Photogramm. Remote Sens. Spat. Inf. Sci. 2016, 41, 903-908. [CrossRef]

116. Michez, A.; Piégay, H.; Jonathan, L.; Claessens, H.; Lejeune, P. Mapping of riparian invasive species with supervised classification of Unmanned Aerial System (UAS) imagery. Int. J. Appl. Earth Obs. Geoinf. 2016, 44, 88-94. [CrossRef]

117. Müllerová, J.; Bartaloš, T.; Brůna, J.; Dvořák, P.; Vítková, M. Unmanned aircraft in nature conservation: an example from plant invasions. Int. J. Remote Sens. 2017, 38, 2177-2198. [CrossRef]

118. Perroy, R.L.; Sullivan, T.; Stephenson, N. Assessing the impacts of canopy openness and flight parameters on detecting a sub-canopy tropical invasive plant using a small unmanned aerial system. ISPRS J. Photogramm. Remote Sens. 2017, 125, 174-183. [CrossRef]

119. Papakonstantinou, A.; Topouzelis, K.; Pavlogeorgatos, G. Coastline Zones Identification and 3D Coastal Mapping Using UAV Spatial Data. ISPRS Int. J. Geo-Inf 2016. [CrossRef]

120. Gonçalves, J.A.; Henriques, R. UAV photogrammetry for topographic monitoring of coastal areas. ISPRS J. Photogramm. Remote Sens. 2015. [CrossRef]

121. Ventura, D.; Bruno, M.; Jona Lasinio, G.; Belluscio, A.; Ardizzone, G. A low-cost drone based application for identifying and mapping of coastal fish nursery grounds. Estuar. Coast. Shelf Sci. 2016, 171. [CrossRef]

122. Casella, E.; Collin, A.; Harris, D.; Ferse, S.; Bejarano, S.; Parravicini, V.; Hench, J.L.; Rovere, A. Mapping coral reefs using consumer-grade drones and structure from motion photogrammetry techniques. Coral Reefs 2017, 36, 269-275. [CrossRef]

123. Ventura, D.; Bonifazi, A.; Gravina, M.F.; Belluscio, A.; Ardizzone, G. Mapping and Classification of Ecologically Sensitive Marine Habitats Using Unmanned Aerial Vehicle (UAV) Imagery and Object-Based Image Analysis (OBIA). Remote Sens. 2018, 10, 1331. [CrossRef] 
124. Parsons, M.; Bratanov, D.; Gaston, K.J.; Gonzalez, F. UAVs, hyperspectral remote sensing, and machine learning revolutionizing reef monitoring. Sensors 2018, 18, 2026. [CrossRef]

125. Ballari, D.; Orellana, D.; Acosta, E.; Espinoza, A.; Morocho, V. Uav monitoring for enviromental management in galapagos islands. Int. Arch. Photogramm. Remote Sens. Spat. Inf. Sci. 2016, XLI-B1, 1105-1111. [CrossRef]

126. Knoth, C.; Klein, B.; Prinz, T.; Kleinebecker, T. Unmanned aerial vehicles as innovative remote sensing platforms for high-resolution infrared imagery to support restoration monitoring in cut-over bogs. Appl. Veg. Sci. 2013. [CrossRef]

127. Chabot, D.; Dillon, C.; Shemrock, A.; Weissflog, N.; Sager, E.P.S. Geo-Information An Object-Based Image Analysis Workflow for Monitoring Shallow-Water Aquatic Vegetation in Multispectral Drone Imagery. ISPRS Int. J. Geo-Inf. 2018. [CrossRef]

128. Pande-Chhetri, R.; Abd-Elrahman, A.; Liu, T.; Morton, J.; Wilhelm, V.L. Object-based classification of wetland vegetation using very high-resolution unmanned air system imagery. Eur. J. Remote Sens. ISSNOnline) J. Eur. J. Remote Sens. 2017, 50, 2279-7254. [CrossRef]

129. Marcaccio, J.V.; Markle, C.E.; Chow-Fraser, P. Unmanned aerial vehicles produce high-resolution, seasonally-relevant imagery for classifying wetland vegetation. Int. Arch. Photogramm. Remote Sens. Spat. Inf. Sci. 2015, 40, 249-256. [CrossRef]

130. Boon, M.A.; Greenfield, R.; Tesfamichael, S. Wetland Assessment Using Unmanned Aerial Vehicle (Uav) Photogrammetry. Int. Arch. Photogramm. Remote Sens. Spat. Inf. Sci. 2016, XLI-B1, 781-788. [CrossRef]

131. Capolupo, A.; Kooistra, L.; Berendonk, C.; Boccia, L.; Suomalainen, J. Estimating Plant Traits of Grasslands from UAV-Acquired Hyperspectral Images: A Comparison of Statistical Approaches. ISPRS Int. J. Geo-Inf. 2015. [CrossRef]

132. Lu, B.; He, Y. Species classification using Unmanned Aerial Vehicle (UAV)-acquired high spatial resolution imagery in a heterogeneous grassland. ISPRS J. Photogramm. Remote Sens. 2017, 128, 73-85. [CrossRef]

133. Mayr, M.J.; Malß, S.; Ofner, E.; Samimi, C. Disturbance feedbacks on the height of woody vegetation in a savannah: a multi-plot assessment using an unmanned aerial vehicle (UAV). Int. J. Remote Sens. 2017, 39, 4761-4785. [CrossRef]

134. Cruzan, M.B.; Weinstein, B.G.; Grasty, M.R.; Kohrn, B.F.; Hendrickson, E.C.; Arredondo, T.M.; Thompson, P.G. Small Unmanned Aerial Vehicles (Micro-UAVs, Drones) in Plant Ecology. Appl. Plant Sci. 2016, 4, 1600041. [CrossRef]

135. Kraaijenbrink, P.D.A.; Shea, J.M.; Pellicciotti, F.; de Jong, S.M.; Immerzeel, W.W. Object-based analysis of unmanned aerial vehicle imagery to map and characterise surface features on a debris-covered glacier. Remote Sens. Environ. 2016, 186, 581-595. [CrossRef]

136. Seier, G.; Kellerer-Pirklbauer, A.; Wecht, M.; Hirschmann, S.; Kaufmann, V.; Lieb, G.K.; Sulzer, W. UAS-based change detection of the glacial and proglacial transition zone at Pasterze Glacier, Austria. Remote Sens. 2017. [CrossRef]

137. Burns, P.; Nolin, A. Using atmospherically-corrected Landsat imagery to measure glacier area change in the Cordillera Blanca, Peru from 1987 to 2010. Remote Sens. Environ. 2014. [CrossRef]

138. Fraser, R.H.; Olthof, I.; Lantz, T.C.; Schmitt, C. UAV photogrammetry for mapping vegetation in the low-Arctic. Arct. Sci. 2016, 2, 79-102. [CrossRef]

139. Malenovský, Z.; Lucieer, A.; King, D.H.; Turnbull, J.D.; Robinson, S.A. Unmanned aircraft system advances health mapping of fragile polar vegetation. Methods Ecol. Evol. 2017. [CrossRef]

140. Birdsong, T.W.; Bean, M.; Grabowski, T.B.; Hardy, T.B.; Heard, T.; Holdstock, D.; Kollaus, K.; Magnelia, S.; Tolman, K. Application and utility of a low-cost unmanned aerial aystem to manage and conserve aquatic resources in four Texas rivers. J. Southeast. Assoc. Fish Wildl. Agencies 2015, 2, 80-85.

141. van Iersel, W.; Straatsma, M.; Middelkoop, H.; Addink, E. Multitemporal Classification of River Floodplain Vegetation Using Time Series of UAV Images. Remote Sens. 2018, 10, 1144. [CrossRef]

142. Woodget, A.S.; Austrums, R.; Maddock, I.P.; Habit, E. Drones and digital photogrammetry: from classifications to continuums for monitoring river habitat and hydromorphology. Wiley Interdiscip. Rev. Water 2017, 4, e1222. [CrossRef]

143. Husson, E.; Hagner, O.; Ecke, F. Unmanned aircraft systems help to map aquatic vegetation. Appl. Veg. Sci. 2013, 17, 567-577. [CrossRef]

144. Hilborn, R.; Arcese, P.; Borner, M.; Hando, J.; Hopcraft, G.; Loibooki, M.; Mduma, S.; Sinclair, A.R.E. Effective Enforcement in a Conservation Area. Science 2006, 314, 1266. [CrossRef] 
145. Edgar, G.J.; Stuart-Smith, R.D.; Willis, T.J.; Kininmonth, S.; Baker, S.C.; Banks, S.; Barrett, N.S.; Becerro, M.; Bernard, A.T.F.; Berkhout, J.; Buxton, C.D.; et al. Global conservation outcomes depend on marine protected areas with five key features. Nature 2014, 506, 216. [CrossRef]

146. Struhsaker, T.T.; Struhsaker, P.J.; Siex, K.S. Conserving Africa's rain forests: Problems in protected areas and possible solutions. Biol. Conserv. 2005. [CrossRef]

147. Di Franco, A.; Thiriet, P.; Di Carlo, G.; Dimitriadis, C.; Francour, P.; Gutiérrez, N.L.; De Grissac, A.J.; Koutsoubas, D.; Milazzo, M.; Otero, M.; Piante, C.; Plass-johnson, J.; Sainz-trapaga, S.; et al. Five key attributes can increase marine protected areas performance for small-scale fisheries management. Sci. Rep. 2016, 1-9. [CrossRef] [PubMed]

148. Olivares-Mendez, M.A.; Bissyandé, T.F.; Somasundar, K.; Klein, J.; Voos, H.; Le Traon, Y. The NOAH Project: Giving a Chance to Threatened Species in Africa with UAVs. In e-Infrastructure and e-Services for Developing Countries. AFRICOMM 2013; Bissyandé, T., van Stam, G., Eds.; Lecture Notes of the Institute for Computer Sciences, Social Informatics and Telecommunications Engineering; Springer: Cham, Switzerland, 2014; Volume 135, pp. 198-208. [CrossRef]

149. Shaffer, M.J.; Bishop, J.A. Predicting and Preventing Elephant Poaching Incidents through Statistical Analysis, GIS-Based Risk Analysis, and Aerial Surveillance Flight Path Modeling. Trop. Conserv. Sci. 2016, 9, 525-548. [CrossRef]

150. Sabella, G.; Viglianisi, F.M.; Rotondi, S.; Brogna, F. Preliminary observations on the use of drones in the environmental monitoring and in the management of protected areas. The case study of "R.N.O. Vendicari", Syracuse (Italy). Biodiversity J. 2017, 8, 79-86.

151. Weber, S.; Knaus, F. Using drones as a monitoring tool to detect evidence of winter sports activities in a protected mountain area. Eco.mont 2017, 9, 30-34. [CrossRef]

152. Bondi, E.; Fang, F.; Hamilton, M.; Kar, D.; Dmello, D.; Choi, J.; Hannaford, R.; Iyer, A.; Joppa, L.; Tambe, M. SPOT poachers in action: Augmenting conservation drones with automatic detection in near real time. In Proceedings of the AAAI Conference on Artificial Intelligence/Thirty-Second AAAI Conference on Artificial Intelligence, New Orleans, LA, USA, 2-7 February 2018.

153. Kamminga, J.; Ayele, E.; Meratnia, N.; Havinga, P. Poaching detection technologies-A survey. Sensors 2018, 18. [CrossRef] [PubMed]

154. Banzi, J.F. A Sensor Based Anti-Poaching System in Tanzania. Int. J. Sci. Res. Publ. 2014, 4, 1-7.

155. Finn, R.L.; Wright, D. Privacy, data protection and ethics for civil drone practice: A survey of industry, regulators and civil society organisations. Comput. Law Secur. Rev. 2016, 32, 577-586. [CrossRef]

156. Duffy, R. Waging a war to save biodiversity: The rise of militarized conservation. Int. Aff. 2014, 90, 819-834. [CrossRef]

157. Shrestha, Y.; Lapeyre, R. Modern Wildlife Monitoring Technologies: Conservationists versus Communities? A Case Study: The Terai-Arc Landscape, Nepal. Conserv. Soc. 2018, 16, 91-101. [CrossRef]

158. Tulloch, V.J.D.; Tulloch, A.I.T.; Visconti, P.; Halpern, B.S.; Watson, J.E.M.; Evans, M.C.; Auerbach, N.A.; Barnes, M.; Beger, M.; Chadès, I.; et al. Why do We map threats? Linking threat mapping with actions to make better conservation decisions. Front. Ecol. Environ. 2015. [CrossRef]

159. Arefin, A.M.E. Proposal of a marine protected area surveillance system against illegal vessels using image sensing and image processing. Acta Ecol. Sin. 2018. [CrossRef]

160. Toonen, H.M.; Bush, S.R. The digital frontiers of fisheries governance: fish attraction devices, drones and satellites. J. Environ. Policy Plan. 2018, 0, 1-13. [CrossRef]

161. Radjawali, I.; Pye, O.; Flitner, M. Recognition through reconnaissance? Using drones for counter-mapping in Indonesia. J. Peasant Stud. 2017, 44, 753-769. [CrossRef]

162. Radjawali, I.; Pye, O. Drones for justice: Inclusive technology and river-related action research along the Kapuas. Geogr. Helv. 2017, 72, 17-27. [CrossRef]

163. Samia, D.S.M.; Angeloni, L.M.; Bearzi, M.; Bessa, E.; Crooks, K.R.; D’Amico, M.; Ellenberg, U.; Geffroy, B.; Larson, C.L.; Loyola, R.; et al. Best Practices Toward Sustainable Ecotourism. In Ecotourism's Promise and Peril; Blumstein, D., Geffroy, B., Samia, D., Bessa, E., Eds.; Springer: Cham, Switzerland, 2017; pp. 153-178. [CrossRef]

164. King, L.M. Will drones revolutionise ecotourism? J. Ecotourism 2014, 13, 85-92. [CrossRef]

165. Chamata, J.E.; King, L.M. The Commercial Use of Drones in U.S. National Parks. Int. Technol. Manag. Rev. 2017, 6, 158-164. [CrossRef] 
166. Themistocleous, K.; Ioannides, M.; Agapiou, A.; Hadjimitsis, D.G. The methodology of documenting cultural heritage sites using photogrammetry, UAV, and 3D printing techniques: the case study of Asinou Church in Cyprus. Proc. SPIE 2015. [CrossRef]

167. Hansen, A.S. Applying visitor monitoring methods in coastal and marine areas - some learnings and critical reflections from Sweden. Scand. J. Hosp. Tour. 2016, 2250, 1-18. [CrossRef]

168. Park, K.; Ewing, R. The usability of unmanned aerial vehicles (UAVs) for measuring park-based physical activity. Landsc. Urban Plan. 2017, 167, 157-164. [CrossRef]

169. Leary, D. Drones on ice: an assessment of the legal implications of the use of unmanned aerial vehicles in scientific research and by the tourist industry in Antarctica. Polar Rec. 2017. [CrossRef]

170. Office of Environment and Heritage. New South Wales National Parks and Wildlife Service (NPWS) Drones in parks policy. Available online: https://www.environment.nsw.gov.au/topics/parks-reservesand-protected-areas/park-policies / drones-in-parks (accessed on 19 October 2017).

171. De Peyer, R. Drones are banned from Royal Parks amid "fears over impact on wildlife and visitor safety." LondonStandard. LondonStandard, 9 March 2015.

172. Su, T.C. Multispectral sensors carried on unmanned aerial vehicle (UAV) for trophic state mapping of the small reservoir in Kinmen, Taiwan. In Proceedings of the International Geoscience and Remote Sensing Symposium (IGARSS), Milan, Italy, 26-31 July 2015; pp. 5348-5351.

173. Ore, J.P.; Elbaum, S.; Burgin, A.; Detweiler, C. Autonomous aerial water sampling. J. Field Robot. 2015, 32, 1095-1113. [CrossRef]

174. Koparan, C.; Koc, A.B.; Privette, C.V.; Sawyer, C.B.; Sharp, J.L. Evaluation of a UAV-assisted autonomous water sampling. Water 2018, 10. [CrossRef]

175. Tóth, V.R. Monitoring Spatial Variability and Temporal Dynamics of Phragmites Using Unmanned Aerial Vehicles. Front. Plant Sci. 2018, 9, 1-11. [CrossRef] [PubMed]

176. Koparan, C.; Koc, A.B.; Privette, C.V.; Sawyer, C.B. In Situ Water Quality Measurements Using an Unmanned Aerial Vehicle (UAV) System. Water 2018, 10, 264. [CrossRef]

177. D'Oleire-Oltmanns, S.; Marzolff, I.; Peter, K.D.; Ries, J.B. Unmanned aerial vehicle (UAV) for monitoring soil erosion in Morocco. Remote Sens. 2012, 4, 3390-3416. [CrossRef]

178. Casella, E.; Rovere, A.; Pedroncini, A.; Stark, C.P.; Casella, M.; Ferrari, M.; Firpo, M. Drones as tools for monitoring beach topography changes in the Ligurian Sea (NW Mediterranean). Geo-Marine Lett. 2016, 36, 151-163. [CrossRef]

179. Casella, E.; Rovere, A.; Pedroncini, A.; Mucerino, L.; Casella, M.; Cusati, L.A.; Vacchi, M.; Ferrari, M.; Firpo, M. Study of wave runup using numerical models and low-altitude aerial photogrammetry: A tool for coastal management. Estuar. Coast. Shelf Sci. 2014, 149, 160-167. [CrossRef]

180. Mokroš, M.; Výbošt'ok, J.; Merganič, J.; Hollaus, M.; Barton, I.; Koreň, M.; Tomaštík, J.; Čerňava, J. Early stage forest windthrow estimation based on unmanned aircraft system imagery. Forests 2017, 8. [CrossRef]

181. Liu, C.-C.; Chen, P.-L.; Matsuo, T.; Chen, C.-Y. Rapidly responding to landslides and debris flow events using a low-cost unmanned aerial vehicle. J. Appl. Remote Sens. 2015. [CrossRef]

182. Jaukovic, I. Unmanned Aerial Vehicles: A new tool for landslide risk assessment. 2017, 1-7.

183. Török, Á.; Barsi, Á.; Bögöly, G.; Lovas, T.; Somogyi, Á.; Görög, P. Slope stability and rockfall assessment of volcanic tuffs using RPAS with 2-D FEM slope modelling. Nat. Hazards Earth Syst. Sci. 2018. [CrossRef]

184. Izumida, A.; Uchiyama, S.; Sugai, T. Application of UAV-SfM photogrammetry and aerial LiDAR to a disastrous flood: multitemporal topographic measurement of a newly formed crevasse splay of the Kinu River, central Japan. Nat. Hazards Earth Syst. Sci. Discuss. 2016, 1-22. [CrossRef]

185. U.S. Geological Survey Volcano Hazards Program. Available online: https://volcanoes.usgs.gov/vsc/ movies/movie_174028.html (accessed on 27 September 2018).

186. Nakano, T.; Kamiya, I.; Tobita, M.; Iwahashi, J.; Nakajima, H. Landform monitoring in active volcano by UAV and SFM-MVS technique. Int. Arch. Photogramm. Remote Sens. Spat. Inf. Sci. 2014, XL-8, 71-75. [CrossRef]

187. Messinger, M.; Silman, M. Unmanned aerial vehicles for the assessment and monitoring of environmental contamination: An example from coal ash spills. Environ. Pollut. 2016, 218, 889-894. [CrossRef]

188. Wing, M.G.; Burnett, J.D.; Sessions, J. Remote Sensing and Unmanned Aerial System Technology for Monitoring and Quantifying Forest Fire Impacts. Int. J. Remote Sens. Appl. 2014, 4, 18. [CrossRef]

189. Cruz, H.; Eckert, M.; Meneses, J.; Martínez, J.F. Efficient forest fire detection index for application in Unmanned Aerial Systems (UASs). Sensors 2016, 16. [CrossRef] 
190. Lorah, P.; Ready, A.; Rinn, E. Using Drones to Generate New Data for Conservation Insights. Int. J. Geospatial Environ. Res. 2018, 5, 2.

191. Karaca, Y.; Cicek, M.; Tatli, O.; Sahin, A.; Pasli, S.; Beser, M.F.; Turedi, S. The potential use of unmanned aircraft systems (drones) in mountain search and rescue operations. Am. J. Emerg. Med. 2017. [CrossRef]

192. Van Tilburg, C.; Brown, S.T.; Ferguson, M. First Report of Using Portable Unmanned Aircraft Systems (Drones) for Search and Rescue. Wilderness Environ. Med. 2017, 15, 12. [CrossRef]

193. Hengstmann, E.; Gräwe, D.; Tamminga, M.; Fischer, E.K. Marine litter abundance and distribution on beaches on the Isle of Rügen considering the influence of exposition, morphology and recreational activities. Mar. Pollut. Bull. 2017, 115, 297-306. [CrossRef] [PubMed]

194. Martin, C.; Parkes, S.; Zhang, Q.; Zhang, X.; McCabe, M.F.; Duarte, C.M. Use of unmanned aerial vehicles for efficient beach litter monitoring. Mar. Pollut. Bull. 2018, 131, 662-673. [CrossRef] [PubMed]

195. Deidun, A.; Gauci, A.; Lagorio, S.; Galgani, F. Optimising beached litter monitoring protocols through aerial imagery. Mar. Pollut. Bull. 2018, 131, 212-217. [CrossRef] [PubMed]

196. Gómez, C.; Green, D.R. Small unmanned airborne systems to support oil and gas pipeline monitoring and mapping. Arab. J. Geosci. 2017, 10. [CrossRef]

197. Martínez-de Dios, J.; de San Bernabé, A.; Viguria, A.; Torres-González, A.; Ollero, A. Combining Unmanned Aerial Systems and Sensor Networks for Earth Observation. Remote Sens. 2017, 9, 336. [CrossRef]

198. Glenn, N.F.; States, U.; Artigas, F.; Environmental, M.; States, U.; Temperton, V.M. Timing Is Important: Unmanned Aircraft vs. Satellite Imagery in Plant Invasion Monitoring. Front. Plant. Sci. 2017, 8, 1-13. [CrossRef]

199. Rodriguez, R.; Jenkins, D.; Leary, J. Enhancing Invasive Species Control with Unmanned Aerial Systems and Herbicide Ballistic Technology. 2017 ASABE Annual International Meeting 2017. [CrossRef]

200. Finn, R.L.; Wright, D. Unmanned aircraft systems: Surveillance, ethics and privacy in civil applications. Comput. Law Secur. Rev. 2012, 28, 184-194. [CrossRef]

201. Stöcker, C.; Bennett, R.; Nex, F.; Gerke, M.; Zevenbergen, J. Review of the Current State of UAV Regulations. Remote Sens. 2017, 9, 459. [CrossRef]

202. Cracknell, A.P. UAVs: regulations and law enforcement. Int. J. Remote Sens. 2017, 38, 3054-3067. [CrossRef]

203. Dormann, C.F.; McPherson, J.M.; Araújo, M.B.; Bivand, R.; Bolliger, J.; Carl, G.; Davies, R.G.; Hirzel, A.; Jetz, W.; Daniel Kissling, W.; et al. Methods to account for spatial autocorrelation in the analysis of species distributional data: A review. Ecography 2007, 30, 609-628. [CrossRef]

204. Wilson, R.P.; McMahon, C.R. Measuring devices on wild animals: What constitutes acceptable practice? Front. Ecol. Environ. 2006, 4, 147-154. [CrossRef]

205. Duriez, O.; Boguszewski, G.; Vas, E.; Gre, D. Approaching birds with drones: First experiments and ethical guidelines. Biol. Lett. 2015. [CrossRef]

206. McEvoy, J.F.; Hall, G.P.; McDonald, P.G. Evaluation of unmanned aerial vehicle shape, flight path and camera type for waterfowl surveys: disturbance effects and species recognition. PeerJ 2016, 4. [CrossRef] [PubMed]

207. Fletcher, S.B.B.A.T. Will drones reduce investigator disturbance to surface-nesting birds? Mar. Ornithol. 2017, $45,89-94$.

208. Scobie, C.A.; Hugenholtz, C.H. Wildlife monitoring with unmanned aerial vehicles: Quantifying distance to auditory detection. Wildl. Soc. Bull. 2016, 40, 781-785. [CrossRef]

209. Lyons, M.; Brandis, K.; Callaghan, C.; Mccann, J.; Mills, C.; Ryall, S.; Kingsford, R. Bird interactions with drones from individuals to large colonies. bioRxiv 2017, 1-10. [CrossRef]

210. Bevan, E.; Whiting, S.; Tucker, T.; Guinea, M.; Raith, A.; Douglas, R. Measuring behavioral responses of sea turtles, saltwater crocodiles, and crested terns to drone disturbance to define ethical operating thresholds. PLoS One 2018, 13, 1-17. [CrossRef] [PubMed]

211. Ditmer, M.A.; Vincent, J.B.; Werden, L.K.; Tanner, J.C.; Laske, T.G.; Iaizzo, P.A.; Garshelis, D.L.; Fieberg, J.R. Bears Show a Physiological but Limited Behavioral Response to Unmanned Aerial Vehicles. Curr. Biol. 2015, 25, 2278-2283. [CrossRef] [PubMed]

212. Pomeroy, P.; O'Connor, L.; Davies, P. Assessing use of and reaction to unmanned aerial systems in gray and harbor seals during breeding and molt in the UK. J. Unmanned Veh. Syst. 2015, 3, 102-113. [CrossRef]

213. Ramos, E.A.; Maloney, B.M.; Magnasco, M.O.; Reiss, D. Bottlenose Dolphins and Antillean Manatees Respond to Small Multi-Rotor Unmanned Aerial Systems. Front. Mar. Sci. 2018, 5, 316. [CrossRef] 
214. Hodgson, J.C.; Koh, L.P. Best practice for minimising unmanned aerial vehicle disturbance to wildlife in biological field research. Curr. Biol. 2016, 26. [CrossRef] [PubMed]

215. Gonzalez, F.; Johnson, S. Standard operating procedures for UAV or drone based monitoring of wildlife. Proceedings of UAS4RS 2017 (Unmanned Aircr. Syst. Remote Sensing), Hobart, TAS, Australia, 24-25 May 2017; pp. 1-8.

216. Grémillet, D.; Puech, W.; Garçon, V.; Boulinier, T.; Le Maho, Y. Robots in ecology: welcome to the machine. Open J. Ecol. 2012, 2, 49-57. [CrossRef]

217. Sepúlveda, A.; Schluep, M.; Renaud, F.G.; Streicher, M.; Kuehr, R.; Hagelüken, C.; Gerecke, A.C. A review of the environmental fate and effects of hazardous substances released from electrical and electronic equipments during recycling: Examples from China and India. Environ. Impact Assess. Rev. 2010, 30, 28-41. [CrossRef]

218. AUVSI Are UAS More Cost Effective than Manned Flights? I Association for Unmanned Vehicle Systems International. Available online: http:/ / www.auvsi.org/are-uas-more-cost-effective-manned-flights (accessed on 15 October 2017).

219. Koski, W.; Abgrall, P.; Yazvenko, S. An Inventory and Evaluation of Unmanned Aerial Systems for Offshore Surveys of Marine Mammals. J. Cetacean Res. Manag. 2011, 11, 239-247.

220. Liao, X.; Zhang, Y.; Su, F.; Yue, H.; Ding, Z.; Liu, J. UAVs surpassing satellites and aircraft in remote sensing over China. Int. J. Remote Sens. 2018, 00, 1-16. [CrossRef]

221. Otero, V.; Van De Kerchove, R.; Satyanarayana, B.; Martínez-Espinosa, C.; Bin Fisol, M.A.; Bin Ibrahim, M.R.; Sulong, I.; Mohd-Lokman, H.; Lucas, R.; Dahdouh-Guebas, F. Managing mangrove forests from the sky: Forest inventory using field data and Unmanned Aerial Vehicle (UAV) imagery in the Matang Mangrove Forest Reserve, peninsular Malaysia. For. Ecol. Manage. 2018, 411, 35-45. [CrossRef]

222. Andrew, M.E.; Shephard, J.M. Semi-automated detection of eagle nests: an application of very high-resolution image data and advanced image analyses to wildlife surveys. Remote Sens. Ecol. Conserv. 2017. [CrossRef]

223. Chabot, D.; Francis, C.M. Computer-automated bird detection and counts in high-resolution aerial images: a review. J. F. Ornithol. 2016, 87, 343-359. [CrossRef]

224. Gonzalez, L.F.; Montes, G.A.; Puig, E.; Johnson, S.; Mengersen, K.; Gaston, K.J. Unmanned aerial vehicles (UAVs) and artificial intelligence revolutionizing wildlife monitoring and conservation. Sensors 2016, 16. [CrossRef]

225. Lhoest, S.; Linchant, J.; Quevauvillers, S.; Vermeulen, C.; Lejeune, P. How many hippos (Homhip): Algorithm for automatic counts of animals with infra-red thermal imagery from UAV. Int. Arch. Photogramm. Remote Sens. Spat. Inf. Sci. 2015, 40, 355-362. [CrossRef]

226. Martin, J.; Edwards, H.H.; Burgess, M.A.; Percival, H.F.; Fagan, D.E.; Gardner, B.E.; Ortega-Ortiz, J.G.; Ifju, P.G.; Evers, B.S.; Rambo, T.J. Estimating distribution of hidden objects with drones: From tennis balls to manatees. PLoS One 2012, 7, 1-8. [CrossRef] [PubMed]

227. Abd-Elrahman, A.; Pearlstine, L.; Percival, F. Development of Pattern Recognition Algorithm for Automatic Bird detection from unmanned aerial vehicle imagery. Surv. L. Inf. Sci. 2005, 65, 37.

228. Longmore, S.N.; Collins, R.P.; Pfeifer, S.; Fox, S.E.; Mulero-Pazmany, M.; Bezombes, F.; Goodwin, A.; De Juan Ovelar, M.; Knapen, J.H.; Wich, S.A. Adapting astronomical source detection software to help detect animals in thermal images obtained by unmanned aerial systems. Int. J. Remote Sens. 2017, 38, 2623-2638. [CrossRef]

229. Hodgson, J.C.; Mott, R.; Baylis, S.M.; Pham, T.T.; Wotherspoon, S.; Kilpatrick, A.D.; Raja Segaran, R.; Reid, I.; Terauds, A.; Koh, L.P. Drones count wildlife more accurately and precisely than humans. Methods Ecol. Evol. 2018, 9, 1160-1167. [CrossRef]

230. Ma, L.; Li, M.; Ma, X.; Cheng, L.; Du, P.; Liu, Y. A review of supervised object-based land-cover image classification. ISPRS J. Photogramm. Remote Sens. 2017, 130, 277-293. [CrossRef]

231. Hill, S.L.; Clemens, P. Miniaturization of high spectral spatial resolution hyperspectral imagers on unmanned aerial systems. Proc. SPIE 2015, 9482. [CrossRef]

232. Lucieer, A.; Malenovsk??, Z.; Veness, T.; Wallace, L. HyperUAS - Imaging spectroscopy from a multirotor unmanned aircraft system. J. F. Robot. 2014. [CrossRef]

233. Turner, D.; Lucieer, A.; Watson, C. An automated technique for generating georectified mosaics from ultra-high resolution Unmanned Aerial Vehicle (UAV) imagery, based on Structure from Motion (SFM) point clouds. Remote Sens. 2012, 4, 1392-1410. [CrossRef]

234. Duarte, L.; Teodoro, A.C.; Moutinho, O.; Gonçalves, J.A. Open-source GIS application for UAV photogrammetry based on MicMac. Int. J. Remote Sens. 2017, 38, 3181-3202. [CrossRef] 
235. Gonçalves, G.R.; Pérez, J.A.; Duarte, J. Accuracy and effectiveness of low cost UASs and open source photogrammetric software for foredunes mapping. Int. J. Remote Sens. 2018, 39, 5059-5077. [CrossRef]

236. Baena, S.; Boyd, D.S.; Moat, J. UAVs in pursuit of plant conservation - Real world experiences. Ecol. Inform. 2017, 2-9. [CrossRef]

237. Lee, J.G.; Kang, M. Geospatial Big Data: Challenges and Opportunities. Big Data Res. 2015. [CrossRef]

238. Solpico, D.B.; Libatique, N.J.C.; Tangonan, G.L.; Cabacungan, P.M.; Girardot, G.; Ezequiel, C.A.F.; Favila, C.M.; Honrado, J.L.E.; Cua, M.A.; Perez, T.R.; et al. Towards a web-based decision system for Philippine lakes with UAV imaging, water quality wireless network sensing and stakeholder participation. In Proceedings of the 2015 IEEE 10th International Conference on Intelligent Sensors, Sensor Networks and Information Processing, ISSNIP 2015, Singapore, 7-9 April 2015.

239. Popescu, D.; Ichim, L.; Stoican, F. Unmanned Aerial Vehicle Systems for Remote Estimation of Flooded Areas Based on Complex Image Processing. Sensors 2017, 17, 446. [CrossRef] [PubMed]

240. Tay, J.Y.L.; Erfmeier, A.; Kalwij, J.M. Reaching new heights: can drones replace current methods to study plant population dynamics? Plant Ecol. 2018, 8. [CrossRef]

241. Berra, E.F.; Gaulton, R.; Barr, S. Commercial Off-The-Shelf Digital Cameras on Unmanned Aerial Vehicles for Multi- Temporal Monitoring of Vegetation Reflectance and NDVI. IEEE Trans. Geosci. Remote Sens. 2017, 1-35.

242. Faye, E.; Rebaudo, F.; Yánez-Cajo, D.; Cauvy-Fraunié, S.; Dangles, O. A toolbox for studying thermal heterogeneity across spatial scales: From unmanned aerial vehicle imagery to landscape metrics. Methods Ecol. Evol. 2016. [CrossRef]

243. Westoby, M.J.; Brasington, J.; Glasser, N.F.; Hambrey, M.J.; Reynolds, J.M. "Structure-from-Motion" photogrammetry: A low-cost, effective tool for geoscience applications. Geomorphology 2012, 179, 300-314. [CrossRef]

244. Dubois, G.; Clerici, M.; Jf, P.; Brink, A.; Palumbo, I.; Gross, D.; Peedell, S.; Simonetti, D.; Punga, M. On the contribution of remote sensing to DOPA, a digitial observatory for protected areas. In Proceedings of the Proceedings of the 34th International Symposium on Remote Sensing of Environment (ISRSE), Sydney, Australia, 10-15 April 2011.

245. Hart, J.K.; Martinez, K. Environmental Sensor Networks: A revolution in the earth system science? Earth-Science Rev. 2006. [CrossRef]

246. Chape, S.; Harrison, J.; Spalding, M.; Lysenko, I. Measuring the extent and effectiveness of protected areas as an indicator for meeting global biodiversity targets. Philos. Trans. R. Soc. B Biol. Sci. 2005, 360, 443-455. [CrossRef]

(C) 2019 by the authors. Licensee MDPI, Basel, Switzerland. This article is an open access article distributed under the terms and conditions of the Creative Commons Attribution (CC BY) license (http://creativecommons.org/licenses/by/4.0/). 